\title{
Slippery Slope Arguments and Legal Reasoning
}

\author{
Eric Lode $†$
}

Slippery slope arguments pervade the legal discourse. Such arguments generally hold that we should resist a particular practice or policy, either on the grounds that allowing it could lead us to allow another practice or policy that is clearly objectionable, or on the grounds that we can draw no rationally defensible line between the two. Using examples of slippery slope arguments that have been invoked in various debates concerning law and social policy, this Comment analyzes the roles that slippery slope arguments can play in legal reasoning.

After discussing the basic structure of slippery slope arguments and distinguishing among some of their different forms, the author argues that the context in which someone invokes a slippery slope argument can influence that argument's strength. The author then discusses some of the reasons why judges may be troubled by the thought of stepping on a slippery slope. While some such worries are unfounded, others cannot be so easily dismissed. The author argues that slippery slope arguments that rely on predictions can be valid arguments. He also both describes some of the factors that can help fuel slides down such slippery slopes and provides some general guidelines for evaluating those slippery slope arguments that rely on predictive claims. The author then describes some of the roles that slippery slope arguments can play in judicial decision making, even in

Copyright $\odot 1999$ Eric Lode and California Law Review, Inc.

$\dagger$ Law Clerk, The Honorable Walter L. Carpeneti, Supreme Court of the State of Alaska; J.D., School of Law, University of California, Berkeley (Boalt Hall), 1999; Ph.D., University of Colorado at Boulder, 1996; B.A., Hope College, 1990. Many of the points made in this Comment derive from a doctoral dissertation on slippery slope arguments that I wrote as a graduate student in philosophy. See Eric Lode, Slippery Slope Arguments and Social Policy Debates (1996) (unpublished Ph.D. dissertation, University of Colorado (Boulder)) (on file with the University of Colorado Library). I would like to thank the members of my dissertation committee, Professors N. Ann Davis, John Fisher, Sam Fitch, Claudia Mills, and Michael Tooley, for all the help and guidance they provided. Special thanks to N. Ann Davis, the chair of my committee, who has influenced my thinking on these and other matters in innumerable ways. I would also like to thank Professor Jan Vctter for helpful comments on an earlier draft of this Comment. Thanks also to Julia Fromholz, Jin Kim, Matt Kline, Ellen LaPointe, Tu Phan, Tracy Phillips, and everyone clse at the California Law Review who has helped with this Comment. Finally, I would like to thank Kim Weaver, both for her support and for discussing these ideas with me. For my parents and grandparents. 
those cases in which a judge thinks that the claims of such arguments do not provide sufficient grounds for resisting the practice under consideration altogether.

In addition, the author argues that slippery slope arguments can be valuable in ways that people often fail to notice. Sometimes, the problems implicit in the case at the top of the slope will be accentuated in the case at the bottom. Reflecting on the latter can illuminate problems associated with the former. Such reflections can provide grounds for resisting the case at the top, even if we are not persuaded by the literal claims of the relevant slippery slope argument. This Comment thus concludes by arguing that there are good reasons for rethinking some of the roles that slippery slope arguments can play in legal debates.

\section{INTRODUCTION}

People often argue that we should resist some practice or policy on the grounds that allowing it could lead us to allow some other practice or policy that is clearly objectionable. Such arguments frequently employ the following question: If we do allow the practice or policy under consideration, then where would we draw the line? This question is generally meant to be rhetorical. Typically, it is not a request for clarification so much as a thinly-veiled assertion that we can draw no rationally defensible line between the practice or policy under consideration and some clearly objectionable one. ${ }^{1}$

Commentators have used numerous different metaphors to refer to arguments that have this rough form. For example, people have called such arguments "wedge" or "thin edge of the wedge," "camel's nose" or "camel's nose in the tent,"3 "parade of horrors" or "parade of horribles,"4

1. Cf. Frederick Schauer, Slippery Slopes, 99 HARv. L. REv. 361, 380 (1985) (noting that some people "regard the peremptory 'Where do you draw the line?' as a knock-down argument").

2. See, e.g., Jonathan Glover, Causing Death and Saving Lives 166-67 (1977) (discussing "wedge" arguments); Yale Kamisar, Some Non-Religious Views Against Proposed "Mercy-Killing" Legislation, 42 MinN. L. Rev. 969, 1030-41 (1958) (using a "wedge" argument to oppose the legalization of euthanasia); Joseph V. Sullivan, The Immorality of Euthanasia, in BenEFICENT Euthanasia 12, 24-26 (Marvin Kohl ed., 1975) (same); Glanville Williams, "Mercy Killing" Legislation-A Rejoinder, 43 MiNN. L. Rev. 1, 9-11 (1958) (criticizing Kamisar's "wedge" argument). According to the wedge imagery, the practice under consideration is like the thin edge of a wedge. Once we insert it into our social fabric, the rest of the wedge is likely to follow. Since such arguments hold that this would be undesirable, the arguments urge us to resist the practice that represents the thin edge of the wedge.

3. See, e.g., Pittsburgh Press Co. v. Pittsburgh Comm'n on Human Relations, 413 U.S. 376, 402 (1973) (Stewart, J., dissenting) ("The camel's nose is in the tent . ..."); Reed v. King, 193 Cal. Rptr. 130, 132 (Cal. Ct. App. 1983) ("The paramount argument against an affirmative conclusion is that it permits the camel's nose of unrestrained irrationality admission to the tent."); GARRETT HARDIN, FILTERS AGAINST Folly 62-65 (1985) (discussing "camel's nose" arguments). Garrett Hardin traces the camel's nose metaphor to Aesop and notes that such arguments metaphorically maintain that "[o]nce you compassionately let [a] camel stick his nose inside the tent," it will be difficult to refuse him further entrance. Id. at 62 . Since we do not want the camel in our tent, we best not let him stick his 
"domino,"s and "this could snowball" arguments. ${ }^{6}$ All of these metaphors snggest that allowing one practice or policy could lead us to allow a series of other practices or policies. ${ }^{7}$

Today, people generally describe such arguments by using the metaphor of the "slippery slope." According to this imagery, allowing the practice or policy under consideration would put us on the top of a "slippery slope." Once there, it would be difficult, if not impossible, for us to prevent a slide to the bottom. Since such arguments allege that this slide would be objectionable or otherwise undesirable, they urge ns to resist the practice or policy under consideration.

Slippery slope arguments (SSAs) play central roles in many legal debates. ${ }^{8}$ Commentators often argue against legalizing active voluntary euthanasia, for example, on the grounds that doing so could eventually lead us to allow involuntary euthanasia, ${ }^{9}$ or to tolerate the sort of society where the elderly and infirm are expected to call for doctors and demand their own deaths. ${ }^{10}$ Opponents of allowing physician-assisted suicide often make similar arguinents. ${ }^{11}$ Indeed, in both Washington v. Glucksberg ${ }^{12}$ and

nose in it in the first place.

4. See, e.g., Diamond v. Chakrabarty, 447 U.S. 303, 316 (1980) ("The briefs present a gruesome parade of horribles."); Douglas WALTON, SLIPPERY SLOPE ARGUMENTS 2 (1992) (stating that some arguments hold that "one step, if taken, will trigger a contagious sequence of steps, ultimately leading to a "parade of horrors"); Kamisar, supra note 2, at 1030-41 (advocating a "parade of horrors" argument against legalizing euthanasia).

5. See WALTON, supra note 4 , at 2 .

6. See id.

7. Margaret Pabst Battin notes, however, that different metaphors suggest different forces that could lead us to allow the series of other practices or policies. See MARGARET PABST BATTIN, Introduction: The Politics of Dying, in THE LEAST WORTH DEATH 1, 21 (1994). She says, for example, that according to the camel's nose argument, "it is the camel's curiosity or appetite that propels it further into the tent...."Id. In contrast, wedge arguments suggest "that someone or something will strike the wedge, for if not, the wedge constitutes no further risk." Id.

8. See, e.g., John D. Arras, The Right to Die on the Slippery Slope, 8 SOC. ThEORY \& PRAC. 285, 287-88 (1982) (suggesting that SSAs have become the most common form of argument against legalizing active voluntary euthanasia); Nils Holtug, Human Gene Therapy: Down the Slippery Slope?, 7 B1OETHICs 402, 402 (1993) ("I think that many of the worries a lot of us intuitively have concerning gene therapy in fact are worries about a slippery slope...."); David Resnik, Debunking the Slippery Slope Argument Against Human Germ-Line Gene Therapy, 19 J. MED. \& PHIL. 23, 23 (1994) ("One of the more influential arguments against human germ-line gene therapy ... is that it would lead us down a slippery slope...."); Schauer, supra note 1, at 363 (suggesting that SSAs have been the central argument used to oppose certain restrictions on the freedom of expression of the Nazis).

9. See, e.g., Kamisar, supra note 2, at 1030-41; 'William Reichel \& Arthur J. Dyck, Euthanasia: A Contemparary Moral Quandary, The LANCET, Dec. 2, 1989, at 1321, 1321-22.

10. See Philippa Foot, Euthanasia, 6 PhIL. \& PuB. AFF. 85, 111-12 (1977).

11. See, e.g., Krischer v. McIver, 697 So. 2d 97, 109 (Fla. 1997) (Harding, J., concurring); Richard Doerflinger, Assisted Suicide: Pro-Choice or Anti-Life?, Hastings Center REP., Jan.-Feb. 1989, at 16, 17-19; Yale Kamisar, Against Assisted Suicide-Even a Very Limited Form, 72 U. DET. Mercy L. Rev. 735, 741, 749-53 (1994); Yale Kanisar, Physician-Assisted Suicide: The Last Bridge to Active Voluntary Euthanasia, in EuTHANASIA EXAMINED 225, 245 (John Keown ed., 1995); The Slippery Slope of Assisted Suicide, S.F. CHRON., Apr. 26, 1999, at A22.

12. 521 U.S. 702 (1997). 
Vacco v. Quill, ${ }^{13}$ the Supreme Court recognized a desire to prevent a slide down a slippery slope as a legitimate state interest that is rationally related to a ban on assisted suicide. ${ }^{14}$

SSAs also play large roles in debates concerning free speech. Frederick Schauer maintains that the real argument in the Skokie $e^{15}$ controversy

was not that freedom of speech in theory ought to protect the Nazis, but rather that denying free speech protection to the Nazis was likely to start us down a slippery slope, at the bottom of which would be the denial of protection to even those who, in theory, ought to be protected. ${ }^{16}$

Similarly, Joel Feinberg states that "the true motivation behind much of the A.C.L.U. opposition to legal action against [the Nazis]" is the concern that if the swastika is "banned today on good grounds, relatively innocuous symbols may be banned tomorrow on not so good grounds." 17

The use of SSAs is not limited to debates concerning euthanasia, assisted suicide, and the freedom of expression of the Nazis; such arguments have been invoked in an amazing array of other debates. SSAs have been used to oppose gun control legislation, ${ }^{18}$ prohibitions on flag burning, ${ }^{19}$ the banning of racist "hate speech" on college campuses, ${ }^{20}$ decriminalizing marijuana, ${ }^{21}$ requiring HIV-positive physicians to disclose their HIV status to their patients, ${ }^{22}$ and extending the classes of persons whose

13. 521 U.S. 793 (1997).

14. See Glucksberg, 521 U.S. at 732 ("[T]he State may fear that permitting assisted suicide will start it down the path to voluntary and perhaps involuntary euthanasia."); id. at $733 \mathrm{n} .23$ ("We agree that the case for a slippery slope has been made out ...."); id. at 735 (stating that the asserted state interests are "unquestionably important and legitimate, and Washington's ban on assisted suicide is at least reasonably related to their promotion"); Vacco, 521 U.S. at 809 (stating that "avoiding a possible slide towards euthanasia" is a "valid and important public interest[l" that "easily satisf[ies] the constitutional requirement that a legislative classification bear a rational relation to some legitimate end").

15. National Socialist Party of Am. v. Village of Skokie, 432 U.S. 43 (1977) (per curiam); Collin v. Smith, 578 F.2d 1197 (7th Cir. 1978) (striking down a Skokie ordinance that prohibited the dissemination of any material that promoted or incited racial or religious hatred); Skokie v. National Socialist Party, 373 N.E.2d 21 (Ill. 1978). At issue in the Skokie cases was whether the Village of Skokie could prevent the Nazis from holding a public march in the Skokie streets. For discussions of the Skokie controversy, see infra Part V.B.2.a and sonrces cited therein.

16. Schauer, supra note 1 , at 363.

17. 2 Joel Feinberg, The Moral Limits of the Criminal Law 93 (1985).

18. See, e.g., David J. Mayo, The Role of Slippery Slope Arguments in Public Policy Debates, 2122 PHIL. ExCHANGE 81, 81 (1990-91) (stating that SSAs "are the primary argument on which the gun lobby relies in opposing even modest gun control-for instance the so-called 'Brady Amendment'").

19. See Texas v. Johnson, 491 U.S. 397, 417 (1989).

20. See Nadine Strossen, Regulating Racist Speech on Campus: A Modest Proposal?, 1990 DUKE L.J. 484, 537-39.

21. See generally WAITON, supra note 4, at 70-71 (discussing an SSA used to oppose the decriminalization of marijuana).

22. See Barry R. Furrow et al., Health Law 418 (3d ed. 1997). 
cases will receive heightened judicial scrutiny. ${ }^{23}$ SSAs also have been used against allowing abortion, ${ }^{24}$ human gene therapy, ${ }^{25}$ various kinds of searches and seizures conducted without a valid warrant, ${ }^{26}$ and granting zoning powers to churches. ${ }^{27}$ This list is by no means exhaustive. As David J. Mayo points out, "[a]nyone who becomes attuned to the role of slope arguments in public policy debates begins to spot them everywhere."2s

But SSAs tend to be inuch more popular in some circles than they are in others. As Wibren van der Burg notes, the SSA "does not enjoy an unqualified popularity: while popular with conservatives and demagogues, it is often feared for its rhetorical force by liberal reformers." ${ }^{29}$ Glanville Williams goes so far as to call such arguments "the truinp card of the traditionalist,"

because no proposal for reform, however strong the arguments in its favour, is immune from the [slippery slope] objection. In fact, the stronger the arguments in favour of a reform, the more likely it is that the traditionalist will take the [slippery slope] objection-it is then the only one lie has. ${ }^{30}$

23. See City of Cleburne v. Cleburne Living Ctr., Inc., 473 U.S. 432,445 (1985) ("[I]f the large and amorphous class of the mentaily retarded were deemed quasi-suspect ... it would be difficult to find a principled way to distinguish a variety of other groups ...."). The Supreme Court also used slippery slope reasoning to support its holding in Bowers v. Hardwick, 478 U.S. 186 (1985), that there is no fundamental right to engage in homosexual sodomy. See id. at 195-96 ("[I]f respondent's submission is limited to ... voluntary sexual conduct between consenting adults, it would be difficult ... to limit the claimed right to homosexual conduct while leaving exposed to prosecution adultery, incest, and other sexual crimes .... We are unwilling to start down that road.").

24. For helpful discussions of SSAs that have been used to oppose legalized abortion, see Clement Dore, Abortion, Some Slippery Slope Arguments and Identity Over Time, 55 PHIL. STUD. 279 (1989), and Joel Rudinow, On the Slippery Slope, 35 ANALYsis 173 (1974).

25. See, e.g., JEREMY RIFKIN, ALGENY 232 (1983); Whether to Make Perfect Human Beings, N.Y. TIMES, July 22, 1982, at A22. For discussion and criticism of some of the SSAs that have been used to oppose allowing human gene therapy, see Holtug, supra note 8, and Resnik, supra note 8.

26. See, e.g., Coolidge v. New Hampshire, 403 U.S. 443, 453-55 (1971) (search and seizure conducted pursuant to a warrant issued by the state official who was the chief investigator and prosecutor in the case); Terry v. Ohio, 392 U.S. 1, 38 (1968) (Douglas, J., dissenting) (stop and frisk); United States v. Rabinowitz, 339 U.S. 56, 79, 82 (1950) (Frankfurter, J., dissenting) (search incident to a lawful arrest).

27. See, e.g., Larkin v. Grendel's Den, Inc., 459 U.S. 116, 125 (1982).

28. Mayo, supra note 18 , at 81 .

29. Wibren van der Burg, The Slippery Slope Argument, 102 EтHIcs 42, 42 (1991).

30. Williams, supra note 2, at 9; see also DAvid LAMB, Down THE SLIPPERY SLOPE at vii (1988) (suggesting that people sometimes criticize SSAs on the grounds that such arguments could be used to oppose any change in the status quo).

Those in favor of reform may also have reason to be wary of SSAs because of the ways in which such arguments have been used to oppose what we would now view as clear instances of social progress. As Mayo says,

Reactionaries in the Soviet Union railed against the first stages of Peristroika and Glasnost on the grounds that they would lead to further disruptions of the old established order and hence ultimately to anarchy. Anti-suffragette sexists warned that if women were allowed to vote, the next thing you know they would be smoking, working outside the home, entering politics, making other demands for equal treatment and consideration, and generally becoming less 
Philosophers and bioethicists tend to be especially critical of SSAs. As Margaret Pabst Battin says, the SSA

has not been in particularly good philosophic repute in recent years, not only because the predictive claims on which it trades are difficult to formulate and support in any rigorous way, but [also] because it is so frequently used in such uncritical ways by those who oppose various forms of social change. ${ }^{31}$

Gerald Dworkin notes that SSAs have recently "acquired a rather shady reputation" in the field of bioethics, ${ }^{32}$ and many introductory logic textbooks now have sections on what has come to be known as the slippery slope fallacy. ${ }^{33}$

Wibren van der Burg is even skeptical about whether SSAs can play helpful roles in legal debates at all. ${ }^{34} \mathrm{He}$ argues that people's views on the strength of particular SSAs tend to be traceable to their basic outlooks: Those with pessimistic outlooks will tend to be persuaded by such arguments, while those with more optimistic outlooks will tend to reject such arguments as implausible. ${ }^{35}$ Because of this, van der Burg suggests that SSAs will be unconvincing to people who have outlooks that differ from those of the arguments' proponents. ${ }^{36}$ As such, he thinks that appeals

submissive and dependent on men. Racists warned that if the slaves were freed all sorts of evils might ensue, including the ultimate horror of intcrracial marriage! Mayo, supra note 18 , at 88 .

But neither the point that SSAs could be used to oppose any change in the status quo, nor the point that SSAs have been used to oppose what we would now view as clear instances of social progress, gives us sufficient grounds for rejecting the claims of all SSAs: People have also used such arguments to oppose arguable instances of decline. As Mayo also says, "most regrettable social or policy trends (e.g., the construction and use of the first nuclear weapons, U.S. Government intervention in South Vietnam, lowering of drinking ages) had their prognosticators, many of whose unheeded warnings were slope arguments whose legitimacy is clear enough in retrospect." Id. at 89.

31. BatTIN, supra note 7, at 21; see also Jeffrey P. Whitman, The Many Guises of the Slippery Slope Argument, 20 Soc. ThEORY \& PRAC. 85, 85 (1994) ("The slippery slope argument is almost universally derided by philosophers as a bad argument.").

32. Gerald Dworkin, Dangerous Ground?, Hastings Center Rep., May-June 1990, at 42, 42 (reviewing LAMB, supra note 30); see also J.A. Burgess, The Great Slippery-Slope Argument, $19 \mathrm{~J}$. MED. ETHICS 169, 170 (1993) (criticizing the sorts of SSAs used to oppose legalizing active voluntary euthanasia on the grounds that such arguments are "typically undetailed" and their claims tend to be "highly immodest").

33. See. e.g., Robert Paul Churchill, Logic: An Introduction 105-07 (2d cd. 1990); Francis Watanabe Dauer, Critical Thinking 369-70 (1989).

34. See van der Burg, supra note 29, at 65.

35. See id. at 64. For further discussion of van der Burg's views rcgarding pessimism and optimism, see infra Part V.A.1. Mayo also argues that differing views on the strength of particular SSAs tend to be traceable to differences in people's basic outlooks: He thinks that those who advance particular SSAs tend to subscribe to different ideologies from those of the critics of sueh arguments. See Mayo, supra note 18, at 95-96. Unlike van der Burg, however, Mayo does not use this point to qucstion the roles that SSAs can play in legal debates. For further discussion of Mayo's views on the relationship between peoplc's ideologies and their assessments of the strength of particular SSAs, see infra Part V.A.2.

36. See van der Burg, supra note 29, at 65 . 
to SSAs are "often futile," and that such appeals may serve to frustrate rather than to further the debates in which people invoke them. ${ }^{37}$

There is thus much disagreement surrounding both SSAs themselves and the roles that they can play in debates concerning law and social policy. Soine people advance SSAs to urge rejection of various practices or policies; others are highly critical of such arguments. At least one cominentator even questions whether appeals to SSAs can play helpful roles in legal debates at all. Given such disagreement, as well as the frequency with which people invoke SSAs, it is rather surprising that so few detailed studies of the slippery slope form of argument have appeared in the pages of law reviews. Philosophers have published more than a handful of works on SSAs, ${ }^{38}$ but only one law review article is devoted to a general study of this sort of argument. ${ }^{39}$

This Comment seeks to analyze the roles that SSAs can play in legal debates. Part I makes some preliminary remarks regarding the basic structure of SSAs. Part II describes some of the different forms that SSAs may take and argues that there is no single, distinctive form of the slippery slope argument. Part III explains a few of the different contexts in which people invoke SSAs. It also argues that the context in which someone uses an SSA can have a great bearing on that argument's strength. For example, largely because of the role that precedent plays in judicial decision making, some SSAs will be more compelling if they are invoked in adjudication than if they are used in a legislative debate.

Part IV discusses some of the reasons why judges may be troubled by the thought of stepping on a slippery slope. First, a judge may object in principle to the idea of stepping on a slope that contains no non-arbitrary stopping place. Second, a judge may worry that stepping on the slope will, as a matter of empirical fact, lead the courts or other governmental entities to allow a series of other practices, at least some of which may be objectionable. The first objection is unfounded; the second concern cannot be so easily dismissed. Part IV argues that SSAs that rely on predictions can be valid arguments. It also describes some of the factors that can help fuel slides down such slippery slopes. Because numerous factors are relevant to evaluating such SSAs, Part IV argues that we can make no sweeping generalizations regarding the strength of such arguments as a class. Part IV does, however, provide general guidelines for evaluating SSAs that rely on predictive claims. It concludes by describing some of the roles that SSAs can play in judicial decision making.

37. Id.

38. See, e.g., LAMB, supra note 30; Walton, supra note 4; Trudy Govier, What's Wrong with Slippery Slope Arguments?, 12 Canadian J. PHIL. 303 (1982); Holtug, supra note 8; Mayo, supra note 18; van der Burg, supra note 29; Whitman, supra note 31; Bernard Williams, Which Slopes are Slippery?, in MORAL DilemMas in MODERN MEdicine 126 (Michael Lockwood ed., 1985).

39. See Schauer, supra note 1. 
Part V introduces a further complication into our assessments of SSAs by arguing that SSAs can be valuable in ways that people often fail to notice. By focusing our attention on undesirable outcomes that might result if a certain practice is allowed, SSAs can help give us grounds for resisting that practice, even if we are skeptical of the literal claims of the SSAs. The problems implicit in the case at the top of the slope will often be accentuated in the case at the bottom. Reflecting on the latter can thus help to illuminate problems with the former. Such reflections can give us reasons for resisting the case at the top, even if we think that we can draw a rationally defensible line along the slope, and that allowing one case would not be likely to lead us to allow the others. Part $\mathrm{V}$ also argues that considering cases toward the bottom of the slope may enable us to do more justice to some of the deeper concerns that lie behind invocations of SSAs. By focusing our attention on a state of affairs in which the corruption of an important value is magnified, SSAs can help us understand how the practice at the top of the slope represents corruption to the SSAs' proponents. Viewing SSAs in this way will often enable considerations of such arguments to further, rather than frustrate, the debates in which they are used. This Comment thus concludes by arguing that there are good grounds for rethinking some of the roles that SSAs can play in legal debates.

\section{I \\ PRELIMINARY REMARKS}

Before analyzing the roles that SSAs can play in legal debates, we must have some understanding of the basic structure of such arguments. As a rough and preliminary characterization, SSAs are arguments that urge us to resist some practice or policy, either on the grounds that allowing it could lead us to allow some other practice or policy that is clearly objectionable, or on the grounds that we can draw no rationally defensible line between the two. ${ }^{40}$ The purpose of this Part and the next is to clarify and refine this rough characterization. This Part makes some preliminary remarks regarding the basic structure of SSAs. Part II notes that although all SSAs share certain features, they are a family of related arguments rather than a class of arguments whose members all share the same form. After describing some of the different forms that SSAs can take, Part II provides a more precise characterization of SSAs.

40. For similar characterizations of SSAs, see TOM L. BEAUCHAMP \& JAMES F. ChILDRESS, PRINCIPLES OF BIOMEDICAL ETHICs 120-23 (2d ed. 1983); LAMB, supra note 30, at 3-4; GLover, supra note 2, at 166-67; Holtug, supra note 8, at 403-04; James Rachels, Euthanasia, in MATTERs OF LiFE AND DeATH 35, 69-71 (Tom Regan ed., 2d ed. 1986); van der Burg, supra note 29, at 43; and Whitman, supra note 31 , at 85-86. 


\section{A. The Series of Intervening and Gradual Steps}

In attempting to characterize SSAs, the first thing one may notice is that they contain references both to the practice under consideration and to the reason that is cited for why we should resist it. But this observation does not tell us very much: We could make the same point about every argument used to oppose some practice or policy.

The main factor that distinguishes SSAs from other arguments is the way that SSAs serve to connect the practice under consideration to the reason cited for why we should resist it. The practice under consideration is the case at the top of the slope; the reason for resisting it is often the case at the bottom. ${ }^{41}$ For the sake of simplicity we can call the former " $A$ " and the latter " $B$." In between $A$ and $B$, however, is a series of other steps; this series is what makes SSAs "slope" arguments. It would not be a slope argument, for example, if one argued to a friend that she should not try cocaine even once because if she does so, she may instantly have a heart attack and die. Since this argument holds that cocaine should be resisted because of its possible direct and immediate dire consequences, the imagery it suggests is more remimiscent of a cliff or a wall than a slope. It would be a slope argument, on the other hand, if one argued to a friend that she should not try cocaine even once because if she does so, she would be likely to do so again, and again, and again, until cocaine may ultimately lead to her demise. The series of intervening and gradual steps between the friend's first use of cocaine and its possible ultimate tragic result is what makes this latter argument a "slope" argument, and thus potentially an SSA.

As discussed in more detail below, some SSAs urge us to resist $A$ on the grounds that allowing it could lead us to allow $B{ }^{42}$ Such arguments hold that there may come to be a causal connection between $A$ and $B$. Other SSAs hold that we should resist $A$ because allowing it would ultimately leave us with no rational grounds for opposing $B .^{43}$ Such arguments generally maintain that there is some sort of logical or conceptual connection between the two. In order to be "slope" arguments, however, both sorts of arguments must make use of a series of interveming and gradual steps that serve to connect the practice under consideration with the reason cited for why we should resist it. Without such a series, an argument would be neither a "slope" argument nor an SSA.4 This series is the main factor that distinguishes SSAs from other arguments.

41. Frederick Schauer refers to the practice or policy under consideration as "the instant case" and the case at the bottom of the slope as "the danger case." Schauer, supra note 1, at 365 .

42. See infra Part II.A.2.

43. See infra Part II.A.1.

44. Other people who suggest that SSAs must make use of a series of intervening and gradual steps include WALTON, supra note 4, at 213-16; Govier, supra note 38; Mayo, supra note 18, at 81; and van der Burg, supra note 29, at 54. 


\section{B. The Idea that the Slope Lacks a Non-Arbitrary Stopping Place}

The series of steps in SSAs often take the form of continuums: Each step in the series will tend to differ from its successive step only incrementally. SSAs often hold, for example, that there are no significant differences between $A$ and $m$, between $m$ and $n, \ldots$ and between $z$ and the objectionable $B$. The supposed similarities between successive steps on the slope is one of the factors that may help make it "slippery." For example, SSAs often suggest that such similarities could lead us to psychologically assimilate each step with its successor, and thereby gradually allow more and more cases on the slope. ${ }^{45}$ If there appear to be no significant differences between $A$ and $m$ and we allow $A$, we may feel psychological pressure to allow $m$ as well. And if there appear to be no significant differences between $m$ and $n$, and we have come to allow $m$, we may then feel psychological pressure to allow $n$. The supposed similarities between successive steps on the slope thus may lead to pressures to move down it. Part IV discusses these points in more detail. ${ }^{46}$

Some commentators suggest that all SSAs make use of the idea that there is no non-arbitrary stopping place anywhere along the slope. ${ }^{47}$ If $A$ does not significantly differ from $m$, which does not significantly differ from $n, \ldots$ which does not significantly differ from $B$, any line that we would draw on the slope may appear arbitrary. According to Bernard Williams, the lack of a non-arbitrary stopping place is what makes the slopes in SSAs slippery. ${ }^{48}$

As Part IV addresses in more detail, the idea that a slope lacks a nonarbitrary stopping place is one of the reasons why courts may be hesitant to step on it. ${ }^{49}$ If we can draw no non-arbitrary line on the slope, a court may think that any such line would be rationally indefensible. It thus may object in principle to stepping on the slope in the first place. A court may also think that the lack of a non-arbitrary stopping point will, as a matter of empirical fact, lead our judicial system to take further steps down the slope. This consideration may also help lead a court to refuse to allow the case at the top.

45. Some commentators use terms such as "psychological slippery slope arguments" to rcfer to SSAs that rely upon points about our psychology as humans. See, e.g., Rachels, supra note 40, at 6971. For discussion of how psychological considerations can help fuel slides down slippcry slopes, see infra Part IV.B.2.d.

46. See infra Part IV.B.2.

47. See Williams, supra note 38, at 126 (stating that all of the arguments that he considers in his essay on SSAs "use the idea that there is no point at which one can non-arbitrarily get off the slope once one has got on it-that is what makes the slope slippery").

48. See id.

49. See infra Part IV.A. 
While many, if not most, SSAs make use of the view that the slope contains no non-arbitrary stopping place, ${ }^{50}$ an SSA need not rely on this idea. ${ }^{51}$ In order to see this, it is helpful to consider the difference between what Bernard Williams calls "reasonable distinctions" and what he calls "effective distinctions." "A reasonable distinction is one for which there is a decent argument, while an effective distinction is one that, as a matter of social or psychological fact, can be effectively defended." 53

Effective distinctions may fail to be reasonable. ${ }^{54}$ As van der Burg points out, "[d]istinctions based on prejudice ... may be unreasonable but highly effective." ${ }^{25}$ Similarly, reasonable distinctions might not be effective ${ }^{56}$ One could argue, for example, that we could non-arbitrarily restrict physician-assisted suicide to only those patients who meet certain extremely well-defined criteria, but that once we allow this practice, such barriers will begin to be eroded. Such a person could argue that although there is some non-arbitrary stopping place along the slope, we would in fact be unlikely to stop there once we step on it. Although this sort of argument concedes that the slope contains a non-arbitrary stopping place, there is no reason why we should not view it as an SSA.

But what would make this slope "slippery"? The answer to this question may make use of a complex array of psychological and social considerations. The proponent of this argument could hold, for example, that allowing physicians to help patients kill themselves would be likely to alter our views, both on the importance of human life and on the role of physicians, in disturbing ways. By allowing physicians to help certain patients kill themselves, we implicitly concede that human life is not sacred or of infinite value, and that the role of the physician is not simply to improve people's health or to help people live. One could argue that making the first concession removes an important psychological barrier we have toward the killing of humans who do not wish to die, and that both concessions increase the likelihood of our coming to tolerate more objectionable forms of "euthanasia."

The proponent of this argument could also argue that aspects of our society are conducive to a slide down the relevant slope. For example, we

50. Indeed, at least one sort of SSA-what this Comment refers to as "rational grounds SSAs"relies almost exclusively on this idea. See infra Part II.A.1.

51. It should be noted, however, that the view that the slope contains no non-arbitrary stopping place appears to follow from the idea that it contains a continuum of closely related cases. If the cases did not form a continuum, there would be a "break" between at least two of them. This "break" would enable us to draw a non-arbitrary line between those two cases. SSAs that hold that the slope does contain some non-arbitrary stopping place are thus unable to hold that the slope forms a continuum.

52. Williams, supra note 38 , at $127-28$.

53. van der Burg, supra note 29 , at 47.

54. See Williams, supra note 38 , at 128.

55. van der Burg, supra note 29 , at $47-48$.

56. See Williams, supra note 38 , at 128. 
have some tendency to base social policy decisions, at least in part, on economic, cost-benefit considerations. This factor increases the likelihood of our gradually coming to tolerate the "euthanasia" of those whom it is very expensive to keep alive. In order to avoid this objectionable result, one could argue that we should not step on the slope in the first place.

An SSA thus need not hold that the slope lacks a non-arbitrary stopping place. Other things being cqual, however, a slope that contains no non-arbitrary stopping place is slipperier than one that does: If any given line on the slope would contain an element of arbitrariness, it may be harder to defend particular stopping places than it otherwise would be.

\section{The Idea that the Practice Under Consideration Is, in Itself, Unobjectionable}

Schauer holds that SSAs contain the implicit concession that the practice or policy under consideration is, in itself, unobjectionable. ${ }^{57}$ As he puts the point, an SSA

necessarily contains the implicit concession that the proposed resolution of the instant case is not itself troublesome. By focusing on the consequences for future cases, we implicitly concede that this instance is itself innocuous, or perhaps even desirable. If we felt otherwise, then we would not employ the slippery slope argument, but would rather claim much more simply that this case, in itself, is impermissible. ${ }^{58}$

While SSAs often appear to concede, at least for the sake of argument, that the practice under consideration is unobjectionable if considered alone, proponents of SSAs tend not to feel this way themselves. ${ }^{59}$ People often appeal to SSAs as simply one argument among many in trying to get us to resist some practice or policy. ${ }^{60}$

Under certain moral theories, it also makes little sense to say that practices or policies are objectionable in themselves. Utilitarians, for example, hold that acts and practices should be judged solely in terms of their consequences: It would be impermissible to perform an act or allow a practice if refusing to do so would instead maximize utility. ${ }^{61}$ If utilitarians are right about this, then acts and practices cannot be objectionable in themselves. Rather, their objectionability (or lack thereof) lies in their consequences. People who subscribe to consequentialist moral theories can

57. See Schauer, supra note 1 , at 369.

58. Id. at 368-69.

59. For more discussion of this point, sce infra Part V.C

60. See, e.g., Kamisar, supra note 2 (offering a variety of arguments against legalizing euthanasia); Sullivan, supra note 2 (same).

61. See generally Jeremy Bentham, An Introduction to the Principles of Morals and Legislation (J.H. Burns \& H.L.A. Hart eds., Clarendon Press 1996) (1789) (explaining and defending utilitarianism). 
thus use SSAs to argue that allowing $A$ is impermissible: Many SSAs hold that allowing $A$ would have tragic consequences; if allowing $A$ would have worse consequences than would a refusal to allow it, consequentialist moral theories tell us that it would be impermissible to allow $A .^{62}$ Since SSAs can be used to argue for the impermissibility of allowing $A$, it is unhelpful to say that SSAs necessarily contain the implicit concession that $A$ is, in itself, unobjectionable.

Some SSAs also suggest that because we can draw no rationally defensible line anywhere along the slope, our moral assessments of $A$ and $B$ must be the same. ${ }^{63}$ But if this is the case and we grant that $B$ is objectionable, consistency requires us to hold that $A$ is objectionable as well. ${ }^{64}$ Sometimes appeals to SSAs are therefore attempts to help us see what their proponents believe is the objectionable nature of $A .^{65}$ While SSAs may implicitly concede that $A$ is unobjectionable if considered alone, such arguments need not make this concession.

\section{Summary}

The main feature that distinguishes SSAs from other arguments is that SSAs hold that the practice under consideration is, or may come to be, connected to the reason that is cited for why we should resist it through a series of intervening and gradual steps. It is this series of steps that makes SSAs "slope" arguments.

62. It is interesting to note that while SSAs that hold that we should resist $A$ on the grounds that allowing it would have dire consequences are esseutially consequentialist arguments, people who invoke such arguments often subscribe to non-consequentialist moral theories. See, e.g., Arras, supra note 8, at 290-91, 295-96 (discussing proponents of SSAs that oppose the legalization of active voluntary euthanasia who subscribe to non-utilitarian ethical theories that emphasize autonomy and rights). For example, people who believe in the sanctity of human life may argue that we should not allow active voluntary euthanasia or physician-assisted suicide on the grounds that doing so would represent an implicit concession that life is not sacred, which could lead to further corruption of our views on the importance of human life. Similarly, people may argue that we should oppose legalized abortion on the grounds that allowing this practice corrupts our views on the importance of human life, which in turn increases the likelihood that we will come to allow active voluntary euthanasia, and then other forms of killing. Such arguments are consequentialist because they hold that euthanasia, physician-assisted suicide, and abortion should be resisted because of the possible objectionable consequences of allowing these practices. People who make such arguments, however, tend to subscribe to moral theories that are more deontological than consequentialist. Indeed, such people may deplore the ways in which utilitarian, cost-benefit considerations are playing greater roles in legal decision making.

63. See infra Part II.A.1.a.

64. If our moral assessments of $A$ and $B$ must be the same, the principle of uriversahizability tells us that we cannot hold both that one is permissible and that the other is not. See, e.g., BEAuchamp \& ChILDREss, supra note 40, at 120. Thus, if there are no relevant differences between $A$ and $B$ and $A$ is permissible, $B$ must also be permissible. But if there are no relevant differences between $A$ and $B$ and $B$ is impermissible, $A$ must be impermissible as well.

65. Cf. van der Burg, supra note 29, at 42 (stating that the view that SSAs concede "that A is in itself morally neutral or eveu justifiable" does not seem very useful because "often the question is precisely whether $A$ is justifiable"). 
Many SSAs also make use of the idea that there is no non-arbitrary stopping place along the slope; this is one of the main factors that may help to make a slope "slippery." SSAs need not, however, hold that the slope lacks a non-arbitrary stopping point. Psychological and social considerations can also make a slope slippery, even if we can non-arbitrarily get off of the slope at some particular place.

SSAs also may concede, at least for the sake of argument, that the practice under consideration is unobjectionable if considered alone. In some cases, however, SSAs are used in an attempt to get us to see the objectionable nature of that practice. Thus, while all SSAs hold that the relevant "slippery slope" provides us with a reason for resisting $A$, different SSAs make use of different points.

II

\section{DIFFERENT TYPES OF SSAS}

Numerous commentators suggest that there is no single, distinctive form of the SSA. ${ }^{66}$ Part I described the basic structure of SSAs and some of the different points of which such arguments may make use. This Part examines other ways of distinguishing between different types of SSAs. First, it discusses the distinction between empirical SSAs and what this Comment refers to as "rational grounds SSAs." Second, it examines Bernard Williams's distinction between "horrible result" SSAs and "arbitrary result" SSAs. ${ }^{67}$

This taxonimizing serves an important purpose. People who invoke SSAs often do so in a less than rigorous manner. ${ }^{68}$ Proponents of such arguments sometimes appear to do little more than baldly assert that we should refrain from allowing $A$ on the grounds that allowing it would put us on a slippery slope. In making this claim, they often give us little explanation of the possible steps on the slope, how we may move from one step to the next, or even why the thought of stepping on the slippery slope should bother us. ${ }^{69}$ As this Part suggests, however, different types of SSAs object to stepping on the slope for different reasons. The remarks of this Part will thus help us discern some of the things that proponents of SSAs may find objectionable about stepping on a slippery slope. This, in turn,

66. See, e.g., BEAUChamp \& CHILDREss, supra note 40, at 120-23; FeINBERG, stupra note 17, at 92-93; Glover, supra note 2, at 166-67; LAMB, supra note 30, at 1-2; WALTON, supra note 4; Peter Allmark, Euthanasia, Dying Well, and the Slippery Slope, 18 J. AdvanCEd NurSING 1178, 1180 (1993); Govier, supra note 38; Holtug, supra note 8, at 403-04; John Keown, Euthanasia in the Netherlands: Sliding Down a Slippery Slope?, in EuthanasIa EXAMINED, supra note 11, at 261, 26162; Rachels, supra note 40, at 69-71; van der Burg, supra note 29, at 43; Whitman, supra note 31, at 85-86; Williams, supra note 38 , at 126-27.

67. See Williams, supra note 38 , at $126-27$.

68. See supra note 31 and accompanying text.

69. Cf. BATTIN, supra note 7, at 22-23 (invoking similar criticisms of some instances of slippery slope reasoning). 
will put us in a better position to evaluate their SSAs, even when their presentations of the arguments leave a lot to be desired.

Ảlthough we can classify SSAs in a few different ways, ${ }^{70}$ this Part argues that all SSAs ultimately make use of at least one of two points. First, some SSAs hold that we should resist $A$ simply because it is at the top of a slope that contains no non-arbitrary stopping place. Second, some SSAs hold that we should resist $A$ because allowing it could, as a matter of empirical fact, lead us to take further steps down the slope. Unlike the former arguments, the latter sort of SSAs predict that we may actually slide down the slope if we step on it. The former sort of SSÁs object in principle to stepping on a slope that lacks a non-arbitrary stopping place.

\section{A. Rational Grounds and Empirical SSAs}

The most common way of classifying SSAs involves a distinction between those that focus on what allowing $A$ would leave us with no rational basis for opposing and those that make predictions about what allowing $A$ could gradually lead us to allow. ${ }^{71}$ This Comment refers to the former sort of SSAs as "rational grounds SSAs" because they rely upon points about what allowing $A$ would ultimately leave us with no rational grounds for refusing to allow if we allow $A .^{72}$ It calls the latter sort of SSAs "empirical SSAs" because such arguments make empirical predictions. ${ }^{73}$ Rational grounds SSAs rely on principled claims, while empirical SSÁs are essentially predictive arguments.

70. See Govier, supra note 38 (distinguishing between four main types of SSAs); see also WALTON, supra note 4 (adopting and elaborating on Govier's distinctions).

71. Commentators who distinguish between SSAs in roughly this way include BEAUCHAMP \& ChILdREss, supra note 40, at 120-23; FEINBERG, supra note 17, at 92-93; Glover, supra note 2, at 166-67; LAMB, supra note 30, at 1-2; Allmark, supra note 66, at 1180; Holtug, supra note 8, at 403-04; Keown, supra note 66, at 261-62; Rachels, supra note 40, at 69-71; van der Burg, supra note 29, at 43; and Whitman, supra note 31 , at 85-86.

72. Philosophers tend to use terms such as "logical slippery slope arguments" to refer to what this Comment calls "rational grounds SSAs." See, e.g., Holtug, supra note 8, at 403; Rachels, supra note 40, at 69-70; van der Burg, supra note 29 , at 43 . The term "logical slippery slope arguments," however, conjures up the idea that allowing the case at the top of the slope would supposedly logically commit us to allowing the case at the bottom. Indeed, philosophers who discuss logical SSAs tend to characterize such arguments in this way. See, e.g., Holtug, supra note 8, at 403; Rachels, supra note 40, at 69-70; van der Burg, supra note 29, at 43. As infra Part II.A.1.b discusses, however, not all such SSAs make this point; some such arguments merely hold that stepping on the slope would leave us with no rational grounds for opposing successive steps, without holding that allowing the case at the top logically commits us to allowing all the others. The term "rational grounds SSAs" thus provides a more accurate characterization of such arguments; it also avoids some of the confusion that may be engendered by using the term "logical SSAs," such as the view that such arguments necessarily hold that allowing $A$ logically commits us to allowing $B$.

73. Other commentators who use the term "empirical" to refer to this sort of SSA include LAMB, supra note 30, at 1-2; Holtug, supra note 8, at 403; Keown, supra note 66, at 261-62; and van der Burg, supra note 29 , at 43 . Sometimes, however, people use terms such as "psychological," See, e.g., Rachels, supra note 40, at 69-71, or "causal," See, e.g., Arras, supra note 8, at 289; Whitman, supra note 31 , at 86 , to refer to this sort of SSA. 


\section{Rational Grounds SSAs}

Rational grounds SSAs rely on the idea that there is no non-arbitrary stopping place anywhere along the slope. Typically, such arguments maintain that there are no important differences between $A$ and $m$, between $m$ and $n, \ldots$ and between $z$ and the clearly objectionable $B$. Such arguments thus hold that we should resist $A$ on the grounds that allowing it would leave us with no rational grounds for refusing to allow $m$, that if we allow $m$, we would have no rational grounds for refusing to allow $n, \ldots$ which would ultimately leave us with no rational grounds for refusing to allow $B$. Because we can draw no non-arbitrary line along the slope, rational grounds SSAs maintain that we should not step on it in the first place. But such arguments do not make predictions about what stepping on the slope may lead us to allow; SSAs that make predictions are empirical SSAs rather than rational grounds SSAs.

For an example of a rational grounds SSA, consider the following argument pertaining to abortion, discussed by Joel Rudinow:

Birth is a morally insignificant event in the history of the born individual. As far as personhood and entitlement to treatment from a moral point of view are concerned, birth, which for the baby is a mere change of environment, is no more significant than the first birthday. But once birth has been demythologized, as well it should be, we are on the slippery slope. For no particular point between birth and conception is a point at which the person/non-person distinction can be non-arbitrarily located, because the differences in development between any two successive intra-uterine points are so unimpressive. Consequently, we are forced to locate the beginning of human life at the point of conception. ${ }^{74}$

This argument thus holds that regarding personhood, ${ }^{75}$ we can draw no non-arbitrary line at any point along the spectrum between a being that has just been conceived ${ }^{76}$ and a new-born baby. The cases on this slope differ

74. Rudinow, supra note 24 , at $173-74$. It should be noted that Rudinow criticizes rather than defends this SSA.

75. Philosophers who speak of "personhood" generally hold that "persons" are beings who have full moral status. See, e.g., Mary Anne Warren, On the Moral and Legal Status of Abortion, Monist, Jan. 1973, at 43. For helpful discussions of the notion of personhood, see THE IDENTITY of PERSONS (Amélie Oksenberg Rorty ed., 1976).

At least in the early 1970s, philosophical debates about abortion were often cast in terms of personhood. See, e.g., Michael Tooley, Abortion and Infanticide, 2 PHIL. \& PuB. AfF. 37 (1972); Warren, supra. For a compelling argument that holds that even if a fetus is a person, it does not follow that abortion is impermissible, see Judith Jarvis Thomson, A Defense of Abortion, 1 PHIL. \& PuB. AFF. 47 (1971). For skepticism regarding the view that the notion of personhood can be used to resolve the abortion debate, see Jane English, Abortion and the Concept of a Person, 5 CANadian J. PhiL. 233 (1975). For further discussion of the notion of personhood and the abortion debate, see LAURENCE H. Trube, Abortion: The Clash of Absolutes 113-38 (1990).

76. It should be noted that such arguments often seem to assume that there is a moment of conception. This assumption appears false. Rather than being an event that takes place at a single and 
from their successive cases only incrementally; as such, they form a continuum. According to proponents of this argument, there are no important moral differences between a being that has just been conceived and the same being one hour later, between this being and the same being an hour after this, and so on. Because there appear to be no significant difference between fetuses (and new-born babies) at any two successive stages of their development, proponents of this SSA hold that we should not allow abortion at all: Doing so would ultimately leave us with no rational grounds for opposing infanticide, which is clearly impermissible. ${ }^{77}$

Rational grounds SSAs thus have close affinities with the ancient sorites paradox. According to this paradox, taking a grain of sand away from a heap of sand makes no significant difference: What we are left with will still be a heap of sand.$^{78}$ As Douglas Walton points out, the sorites paradox nuaintains that each time we take a grain of sand away from a heap, it will make no difference "because one grain is too small to make a difference between something being a heap or not."79 Repeated long enough, however, "this [line of] reasoning will become absurd, for it will become obvious that what is left can no longer be described as a heap."80

Like the sorites paradox, rational grounds SSAs make use of a spectrum of cases, each of which differs from the next case in the spectrum only incrementally. For example, rational grounds SSAs hold that there are no significant differences between $A$ and $m$, between $m$ and $n$, and so on. The sorites paradox holds that in terms of heapness, there are no significant differences between 1,000 grains of sand and 999 grains, between 999 grains and 998 grains, and so on.

Both the sorites paradox and rational grounds SSAs may also play upon the vagueness of important concepts. The sorites paradox plays upon the vagueness of the concept "heap," while the above SSA plays upon the vagueness of the concept "personhood." The close affinities between the

distinct moment in time, conception seems to be a process that takes about twenty-four hours. See Karen Dawson, Fertilization and Moral Status: A Scientific Perspective, in EMBrYo Experimentation 43 (Peter Singer et al. eds., 1990).

77. Some people think, however, that infanticide is not clcarly impermissible. See, e.g., MICHAEL TOOLEY, ABORTION AND INFANTICIDE (1983); Tooley, supra note 75. But the slippery slope line of reasoning can be repeated to whenever it is that one thinks that killing would become clearly impermissible. As proponents of this SSA could argue, there are no important moral differences between a new-born baby and the same baby one hour latcr, between this baby and the same baby an hour after this, etc.

78. For helpful discussions of the sorites paradox, see Michael DUMmetT, Wang's Paradox, in Truth AND Other EnIGMas 248 (1978); Richmond Campbell, The Sorites Paradox, 26 PHIL. STUD. 175 (1974); and Stephen E. Weiss, The Sorites Fallacy: What Difference Does a Peanut Make?, 33 SYNTHESE 253 (1976).

79. WaLTON, supra note 4 , at 38-39.

80. Id. at 39 .

81. For more discussion of how SSAs may play upon the vagueness of concepts, see infra Part IV.B.2.b. 
sorites paradox and rational grounds SSAs motivate Walton to call this version of the SSA "the sorites slippery slope argument."

\section{a. SSAs that Make Points About What We Would Logically Commit Ourselves to Allowing}

Philosophers often maintain that rational grounds SSAs hold that allowing the case at the top of the slope logically commits us to allowing the case at the bottom. ${ }^{83}$ It is arguable, for example, that the above SSA regarding abortion holds that allowing abortion at any stage of fetal development logically commits us to allowing infanticide.

Consider also the following SSA against allowing any form of euthanasia, advanced by the Bishop Joseph V. Sullivan:

Once a man is permitted on his own authority to kill an innocent person directly, there is no way of stopping the advancement of that wedge. There [are] no longer any rational grounds for saying that the wedge can advance so far and no further. Once the exception has been admitted, it is too late; hence, the grave reason why no exception may be allowed. That is why euthanasia under any circumstances must be condemned. ${ }^{84}$

This argument implicitly maintains that we can draw no rationally defensible line between any two successive cases on the slope between, for example, the active voluntary euthanasia of a person in great pain who wants to die and other, clearly impermissible forms of killing, such as the killing of a person who is not in great pain and expresses a desire to live. According to this argument, if we allow active voluntary euthanasia, we would then have no rational grounds for refusing to allow other forms of killing. And if we allow these other forms of killing, we would then have no rational grounds for refusing to allow others, and then others, and then still others, until we would finally have no rational grounds for refusing to allow forms of killing that are clearly impermissible.

In criticizing this SSA, James Rachels says,

There are rational grounds for distinguishing between the man in agony who wants to die and other cases, such as that of an old infirm person who does not want to die. It is easy to say what the rational ground is. It is simply that in the first case the person requests death, whereas in the second case the person does not request it. Moreover, in the first case, the person is suffering terribly, and in the second case the person is not. These are morally relevant differences to which we can appeal in order to distinguish the cases; therefore, we are not logically committed to accepting

82. WALTON, supra note 4 , at 37-68.

83. See supra note 72.

84. Sullivan, supra note 2 , at 24. 
"euthanasia" in the second case merely because we approve it in the first. ${ }^{85}$

Because there are relevant differences between the two cases, Rachels is correct that allowing the former does not logically commit us to allowing the latter. The two cases are distinguishable, so we can consistently hold that the former is permissible while the latter is not. Our moral assessments of the two thus need not be the same. ${ }^{86}$

Similar criticisms can be made of other SSAs that hold that allowing the case at the top of the slope logically commits us to allowing the case at the bottom. Trudy Govier argues that such SSAs commit what she calls the "fallacy of assimilation." According to Govier,

To infer that differences of degree cannot cumulate into a significant difference simply on the grounds that they are differences in degree is mistaken. ... Differences of degree though separately minute and insignificant, may cumulate to be significant. Anyone who infers from their separate minuteness and insignificance, their collective insignificance, makes a logical mistake. $^{88}$

To illustrate this point, Govier uses the example of height: Although there is no specific one-sixteenth of an inch increment in height between four feet and seven feet that makes the difference as to whether or not a person is tall, we are not committed to saymg that a person four feet in height is "tall" simply because we use this term to describe someone who is seven feet in height. ${ }^{89}$ Even if there appear to be no significant differences between successive cases on the slope, there may be a big difference between the case at the top and the case at the bottom. Allowing the former thus will not necessarily logically commit us to allowing the latter. SSAs that rely upon a series of incremental differences to hold that allowing the case at the top of the slope logically commits us to allowing the case at the bottom thus make use of a logical sleight-of-hand.

85. Rachels, supra note 40 , at $69-70$.

86. It is unclear, however, if the SSA that Rachels criticizes really does hold that allowing one form of "euthanasia" logically commits us to allowing all others. This SSA may simply be making the point that we can draw no non-arbitrary line anywhere along the slope, without holding that allowing one case logically commits to allowing all the rest. As such, it is unclear if Rachels's remarks actually refute this SSA. For discussion of how an SSA can maintain that we can draw no non-arbitrary line along the slope without holding that allowing one case logically commits us to allowing all the others, see infra Part II.A.1.b.

87. Govier, supra note 38 , at 307.

88. Id.

89. See id. 


\section{b. SSAs that Focus on What Allowing A Would Leave Us with No Rational Basis for Opposing}

Rational grounds SSAs need not, however, hold that allowing the case at the top of the slope logically commits us to allowing the case at the bottom. Indeed, it is arguable that Bishop Sullivan's argument regarding euthanasia does not so hold. A proponent of this sort of argument could admit that there are significant differences between the case at the top and the case at the bottom, but argue that we still should not step on the slope because we have no principled basis for drawing any line upon it.

For an example of this sort of SSA, consider the following argument against allowing any form of human gene therapy:

Repairing a defect is one thing, but once that is routine, it will become much harder to argue against adding genes that confer desired qualities, like better health, looks or brains. There is no discernible line to be drawn between making inheritable repairs of genetic defects, and improving the species. ${ }^{90}$

This argument holds that we can draw no non-arbitrary line between using gene therapy to cure obvious "defects" and using it to confer desired characteristics. Because of this, the argument suggests that we should not use human gene therapy at all.

But the argument does not need to maintain that allowing the case at the top of the slope logically commits us to allowing all of the others. Indeed, the argument states that "[r]epairing a defect is one thing," suggests that its proponent is prepared to admit that there is a difference between using gene therapy to cure "defects" and using it to confer desired qualities. Even though there is this difference, one could still argue that there is a gray zone between the permissible and the impermissible cases on the slope, and that this gray zone prevents us from drawing a rationally defensible line upon it. As such, the argument's proponent can hold that slippery slope considerations present us with a principled reason for refusing to step on the slope in the first place, even though some of the cases on the slope are permissible if considered alone. Because rational grounds SSAs can admit that there are relevant differences between cases on the slope, the arguments need not hold that allowing one case logically commits us to allowing all the others. ${ }^{92}$

Since such SSAs may admit that there are relevant differences between the case at the top of the slope and the case at the bottom, it is

90. Whether to Make Perfect Human Beings, supra note 25, at A22.

91. Id. (emphasis added).

92. For further support of the view that an SSA can hold that the slope contains no non-arbitrary stopping place without necessarily holding that allowing the case at the top logically commits us to allowing all the others, see Eric Lode, Slippery Slope Arguments and Social Policy Debates 54-59 (1996) (unpublished Ph.D. dissertation, University of Colorado (Boulder)) (on file with the University of Colorado Library). 
unclear whether we can refute such SSAs by pointing to these differences. This Comment argues later, however, that such SSAs are still generally unfounded: Even lines containing an element of arbitrariness can be rationally defensible. ${ }^{93}$

\section{Empirical SSAs}

Unlike rational grounds SSAs, empirical SSAs rely on points about what stepping on the slope may ultimately lead us to allow. While rational grounds SSAs make principled objections to stepping on a slope that lacks a non-arbitrary stopping place, empirical SSAs hold that we should resist $A$ because of the possible negative consequences of allowing it. Empirical SSAs are thus predictive rather than purely principled.

Empirical SSAs may make use of rational grounds slippery slope considerations. Indeed, factors that might help propel us down the slope include the difficulties in drawing lines upon it, or the vagueness of key terms that would be used in social policies or judicial opinions. ${ }^{94}$ The steps on the slope of an empirical SSA can even be the same as the steps on the slope of a rational grounds SSA. A rational grounds SSA may hold that we can draw no non-arbitrary line between $A$ and $m$, between $m$ and $n, \ldots$ and ultimately between $z$ and the objectionable $B$. Similarly, an empirical SSA may hold that allowing $A$ would make us likely to allow $m$, which would make us likely to allow $n, \ldots$ which would ultimately make us likely to allow $B$. The predictive nature of empirical SSAs is what distinguishes them from their rational grounds counterparts.

\section{B. Horrible Result and Arbitrary Result SSAs}

Bernard Willians provides us with another way to distinguish between SSAs. According to Wilhams, some SSAs object to what is supposedly at the bottom of the slope, while others object to the fact that it is a slope..$^{95}$ Williams calls the first sort of SSA "the horrible result argument" and the second "the arbitrary result argument." 96 This Section explains Williams's distinction.

\section{Horrible Result SSAs}

Horrible result SSAs hold that we should resist $A$ because allowing it would put us on a slippery slope, at the bottom of which is a case that is clearly objectionable. Such arguments may hold that allowing $A$ increases the likelihood that we shall come to allow $B$, or that there is no rationally

\footnotetext{
93. See infra Part IV.A.

94. For discussion of how the vagueness of key terms can be conducive to slides down slippery slopes, see infra Part IV.B.2.b.

95. See Williams, supra note 38, at 126.

96. Id.
} 
defensible line that we can draw on the slope that connects the two. As such, horrible result SSAs may be of either the empirical or the rational grounds variety. Indeed, the SSAs considered in this Part so far can all be characterized as horrible result SSAs because they all hold that the case at the bottom of the slope is objectionable.

\section{Arbitrary Result SSAs}

But not all SSAs rely on views about the objectionability of the case at the bottom of the slope. Williams isolates one sort of SSA, which he calls "the arbitrary result argument," that objects to the idea that there is a slope rather than to that which is at the bottom of it. ${ }^{97}$ Arbitrary result SSAs rely on the point that once we have gotten on the slope, subsequent discriminations will be arbitrary; ${ }^{98}$ it is this arbitrariness to which such arguments object. Williams gives the following example:

Suppose that some tax relief or similar benefit is allowed to couples only if they are legally married. It is proposed that the benefit be extended to some couples who are not married. Someone might not object to the very idea of the relief being given to unmarried couples, but nevertheless argue that the only non-arbitrary line that could be drawn was between the married couples and the unmarried, and that as soon as any unmarried couple was allowed the benefit, there would be too many arbitrary discriminations to be made. ${ }^{99}$

Arbitrary result SSAs thus objeet to the lack of a non-arbitrary stopping place along the slope; such arguments need not hold that any particular case on the slope is objectionable if considered alone. As Walton says, the intolerable outcome according to arbitrary result SSAs "is a series of unclear or arbitrary decisions about what to include," 100 rather than an acceptance of (or a lack of rational basis for opposing) some case that is objectionable in itself.

Like horrible result SSAs, we can fit arbitrary result SSAs into the empirical and rational grounds taxonomy. In some cases, proponents of arbitrary result SSAs may mean to assert that if we allow $A$, we will in fact come to draw an arbitrary line. Since such arguments make a point about what may in fact happen, they are empirical SSAs. In other cases, however, proponents of arbitrary result SSAs may merely mean to assert that if we allow $A$, any subsequent line that we draw would be arbitrary. If such people do not make the prediction that we will in fact come to draw an arbitrary line, and instead make a principled objection to the idea of stepping

\footnotetext{
97. Id.

98. See id. at 127.

99. Id.

100. WaLTON, supra note 4, at 157.
} 
on a slope that contains no non-arbitrary stopping place, their arguments are of the rational grounds variety.

One may wonder here, however, if there really is a difference between those rational grounds SSAs whose slopes contain an objectionable case and those whose slopes do not. As discussed above, rational grounds SSAs make principled objections to stepping on a slope that contains no nonarbitrary stopping place. ${ }^{101}$ As such, it may not matter whether the bottom of the slope is objectionable in itself: Principled objections to stepping on a slope that lacks a non-arbitrary stopping point would appear to have the same force whether or not the slope contains an objectionable case.

Rational grounds SSAs that make use of an objectionable case, however, may have more rhetorical force than those that do not. Principled points about arbitrariness at least seem more worrisome if allowing $A$ could ultimately leave us with no rational basis for opposing some case that is clearly objectionable. It is also frequently unclear whether a person making use of an SSA means to make a principled or an empirical claim. ${ }^{102}$

While in practice it may be difficult to distinguish empirical from rational grounds SSAs, this distinction still makes conceptual sense: The former SSAs make predictive claims, while the latter make principled objections to stepping on a slippery slope that contains no non-arbitrary stopping place. But if one simply objects in principle to stepping on a slippery slope, it does not matter from an analytical point of view whether the slope contains a case that is, in itself, objectionable.

Even if there is ultimately no difference between the sort of objections that lie behind rational grounds SSAs that hold that the slope contains an objectionable case and those that do not, Williams's distinction leads us to an important poimt: Some SSAs hold that no particular case on the slope is objectionable m itself. ${ }^{103}$

101. See supra Part II.A.1.

102. See Mayo, supra note 18 , at 85 (arguing that we cannot always effectively distinguish between empirical SSAs and rational grounds SSAs).

103. Govier isolates another sort of SSA that need not hold that any case on the slope is objectionable in itself. See Govier, supra note 38, at 311. This sort of argument, which Govier calls the "feasibility precedent" SSA, id., is closely related to the arbitrary result SSA. For an example of a feasibility precedent SSA, consider the following argument that derives from an SSA discussed by Mayo, supra note 18 , at 85 , in which an employee asks a boss for a raise and the boss responds by saying:

As much as I would love to give you a raise, I simply cannot. For if I did give you a raise, I would then be obligated to give a raise to the next employee who asked me to do so, and then to the next employee who asked, and then to the next, and then still to the next. Although each employee may deserve a raise, giving a raise to all of them is impossible-its expense would drive me to financial ruin.

As Govier notes, this sort of argument relies on the points that: (1) consistency requires us to treat like cases alike, see Govier, supra note 38, at 309, and (2) "the cumulative effect of allowing a number of cases, each of which might be deserving and legitimate when considered separately, is overload," $i d$. at 311. According to Walton, such SSAs hold that the intolerable outcome "is an unworkable or impractical rule." WALTON, supra note 4, at 158. 


\section{A More Precise Characterization of SSAs}

We are now in a position to offer a more precise characterization of SSAs: SSAs are arguments that urge us to resist some practice or policy on the grounds that allowing it would either increase the likelihood of our coming to allow, or leave us with no rational grounds for opposing, each successive case in a whole series of other cases. Generally speaking, allowing at least one case in the series, or all of them taken together, would be objectionable or at least not feasible. Some SSAs, however, simply object in principle to stepping on a slope that lacks a non-arbitrary stopping place.

Given these points, there is no single, distinctive form of the slippery slope argument. Different SSAs hold that stepping on the slope is objectionable for different reasons. Some SSAs are essentially predictive arguments, while others rely on more principled points. As such, SSAs are a family of related arguments rather than a class of arguments whose members all share the same form. In evaluating SSAs that are invoked in a less than rigorous manner, we should thus consider whether either of these points gives us grounds for resisting the practice under consideration.

III

\section{The Contexts IN Which People Invoke SSAs}

In order to give properly evaluate many SSAs, one should pay attention to the contexts in which they are invoked. For those concerned with legal issues, two contexts are especially relevant: (1) debates concerning legislation and social policy, and (2) adjudication.

The context in which someone invokes an SSA can have a large bearing on the strength of that argument. ${ }^{104}$ This is true of empirical SSAs in particular because such arguments rely on predictions about the world. ${ }^{105}$ As Rudinow says, "the risks of a given innovation leading to moral degeneration (or to some other bad end like the abusive accumulation of political power) depend not only on the nature of the innovation but also on the context within which it is contemplated and

Feasibility precedent SSAs also fit into the empirical and rational grounds taxonomy. If one claims that allowing one case increases the likelihood of allowing all the others, her argument is an empirical SSA. But if she instead has only a principled objection to stepping on a slippery slope that contains no non-arbitrary stopping place, her argument is a rational grounds SSA. In some cases it may be unclear which sort of worry underlies a particular SSA. In order to evaluate such arguments, we may thus have to ask whether we can draw a rationally defensible line along the slope and whether we have grounds for fearing that allowing one case will eventually lead us to allow others.

104. See, e.g., LAMB, supra note 30, at 1-2; WALTON, supra note 4, at 151-53; Williams, supra note 38, at 185; Joel Rudinow, David Lamb's Down the Slippery Slope: Arguing in Applied Ethics, IX Canadian Phit. Reviews 26, 28 (1989) (book review).

105. But cf. van der Burg, supra note 29, at 44-51 (arguing that the strength of what he calls "logical SSAs" can be influenced by the context in which someone invokes them). See also infra note 110 (discussing van der Burg's views). 
proposed." 106 To illustrate this point, Rudinow suggests that it is probably a case of bad slippery slope reasoning to tell a college student that he should not have a single drink of alcohol on the grounds that doing so may lead him to become a homeless alcoholic. ${ }^{107}$ But if the same statement is made to a recovering alcoholic who has recently lost his job, been evicted, been notified of a tax audit, been told that his wife is filing for divorce, and is conteinplating taking, his first drink in five years, the statement "is probably pretty decent advice." 108 The context in which someone invokes an SSA thus can have a large influence on the arguinent's strength.

\section{A. Social Contexts}

Social contexts can greatly influence the strength of those empirical SSAs invoked in debates concerning social policy. Consider SSAs that hold that we should not legalize active voluntary euthanasia because doing so could lead us to allow other forms of killing, and then others, and then still others, until we finally come to tolerate the involuntary euthanasia of political or social "undesirables," racial and ethnic minorities, the elderly and the handicapped, or people whom it is very expensive to keep alive. Other things being equal, a society that is highly racist and prejudiced toward the elderly and the handicapped, and that bases its social policy decisions largely upon economic, cost-benefit considerations, is much more likely to slide down the relevant slope than a largely non-prejudiced society that places great emphasis upon individual rights, autonomy, and the value of human life. ${ }^{109}$ What appears to be the same empirical SSA can

\section{Rudinow, supra note 104 , at 28 .}

107. See id.

108. Id.

109. Cf. Arras, supra note 8 , at 298 (stating that our society's concern with individual rights provides us with grounds for "guarded optimism that we will not plunge down the slope" if we allow active voluntary euthanasia).

Some commentators argue that the toleration of active voluntary euthanasia in the Netherlands has led to a slide down a slippery slope in that country. See, e.g., Keown, supra note 66, at 289 ("[T] Dutch ... experience lends weighty support to the slippery slope argument . . . . Within a decadc, the so-called strict safeguards against the slide have proved . . . ineffectual; non-voluntary euthanasia is now widely practised and increasingly condoned in the Netherlands."). There are, however, numerous differences between the social context of the Netherlands and that of the United States. See MARGARET Pabst Battin, A Dozen Caveats Concerning the Discussion of Euthanasia in the Netherlands, in ThE LEAST WORTH DEATH, supra note 7, at 130 (dcscribing some of these differences). These differences may make it so that considerations of the Dutch experience alone will not enable us to definitively evaluate the relevant SSAs that people invoke in the United States. Battin also notes that proponents of legalizing active voluntary euthanasia tend to paint a much different picture of the Dutch experience than do opponents of legalizing this practice. See id. at 130 ("In the United States, those who think euthanasia should be legalized often cite the Netherlands as a unodel of conscientious practice; those who think it should not be legalized, on the other hand, often claim that [the] Dutch practice already involves abuse and will inevitably lead to more."). This consideration suggests that it may be wise to take evaluations of the Dutch experience with a grain of salt. Arguably, our views on whether we should allow active voluntary euthanasia in the United States will color our views on the experience with euthanasia in the Netherlands. 
thus be a better predictive argument if it is made in some social contexts than if it is made in others.

\section{B. Legislative Debates and Adjudication}

Whether someone invokes an SSA in a legislative debate or in adjudication can also bear on that argument's strength. In some cases, an SSA invoked in adjudication may have more force than a similar SSA invoked in the policy-making realm. ${ }^{110}$ This is true partially because of the important role that precedent plays in judicial decision making. Under the principle of stare decisis, ${ }^{111}$ lower courts are bound to respect the precedents set by higher courts in their jurisdiction. Courts are also under a strong obligation to follow their own precedents; typically, it takes extremely weighty reasons for a court to depart from precedent and overrule a previous decision.

Judges also tend to place a premium both on drawing non-arbitrary, rationally defensible lines ${ }^{112}$ and on maintaining a coherent, consistent body of case law within a particular jurisdiction. If one case holds that $A$ is allowable, and the court that decided that case is considering whether to allow $m$, the court is likely to think that it must have a rational basis for distinguishing between $A$ and $m$ to justify a refusal to allow the latter. If the court can find no rational basis for distinguishing between the two and it believes that the case allowing $A$ is still good law, it is likely to take its allowance of $A$ as a precedent for allowing $m$. These factors make the judicial arena a realm that can be particularly conducive to slides down slippery slopes. ${ }^{113}$

Legislative reasoning, however, does not work in the same way. If a legislature passes a statute allowing $A$, it is not then under an obligation to also pass a statute allowing $m$, even if there appear to be no significant

110. van der Burg also argues that SSAs can have different degrees of force depending on whether they are invoked in adjudication or in the legislative realm. See van der Burg, supra note 29, at 43-54. He thinks, however, that while what he calls "logical slippery slope arguments" tend to have greater validity in adjudication than in legislative debates, empirical SSAs tend to have greater validity in the legislative context than in the adjudicatory one. Id. at 53. As this Part argues, however, the role that precedent plays in adjudication suggests that many empirical SSAs will have greater force in adjudication than similar empirical SSAs invoked in the legislative context. See infra notes $111-16$ and accompanying text.

111. "Stare decisis" is an abbreviation of "stare decisis et non quieta movere," which means "to stand by what has been decided and not to disturb setticd points." MARTIN P. GoldiNG, LEGAL REASONING 98 (1984).

112. See, e.g., Hoctor v. United States Dep't of Agric., 82 F.3d 165, 170 (7th Cir. 1996) (Posner, C.J.) ("[Clourts are uncomfortable with making arbitrary ehoices. They see this as a legislative function."). This Comment argues, however, that even in the adjudicatory context, lines containing an element of arbitrariness can be rationally defensible. See infra Part IV.A. Judges may thus be more concerned about seemingly arbitrary lines than they need to be. See infra Part IV.B.2.a.

113. For a more detailed discussion of these points, see infra Part IV.B.2.a. 
differences between the two. ${ }^{114}$ Stare decisis does not apply in the legislative context, and legislators do not place the same premium on drawing non-arbitrary lines that judges do. As van der Burg notes, "[1] egislation often dictates arbitrary limits. There is no essential distinction between 30 mph and 31." "15 Yet once a legislature decides that 30 miles per hour is the speed limit, that is essentially the end of the matter. It is unlikely that we will be able to convince a legislature to raise the speed limit to 31 by arguing that there are no significant differences between 30 and 31 . The legislature has already spoken regarding the speed limit; it is largely irrelevant that its distinction is rather arbitrary.

Although empirical SSAs can be valid both in adjudication and in the policy-making context, ${ }^{116}$ this Section illustrates that the force of a particular SSA may depend at least partially on the context in which someone invokes it. The role that precedent plays in judicial decision making, combined with the premium that judges place on drawing non-arbitrary, rationally defensible lines, make it so that certain SSAs will have more force if people use them in adjudication than if people use them in legislative debates.

\section{IV \\ SSAS AND JUdICIAL DECISION MAKING}

Judges often unake references and allusions to the slippery slope form of argument. ${ }^{117}$ Justice Brennan employed a rather famous SSA in writing for the majority in Texas v. Johnson. ${ }^{118}$ At issue there was Gregory Lee Johnson's conviction for desecration of a venerated object in violation of the Texas Penal Code. ${ }^{119}$ Johnson had burned an American flag during a political demonstration in Dallas "to protest the policies of the Reagan administration and of certain Dallas-based corporations." 120 The Supreme

114. A court interpreting the statute allowing $A$ may, however, find that since there are no significant differences between $A$ and $m$, the statute allows both.

115. van der Burg, supra note 29 , at 48.

116. See infra Part IV.B.1.

117. An April 2, 1999 search of the ALLCASES database in Westlaw revealed that the term "slippery slope" has been used in 517 cases. While some of these cases pertain to ski injuries or "slip and fall" accidents, the majority do not. This Westlaw search did not include those cases in which judges used metaphors such as "wedge" or "camel's nose" instead of "slippery slope." It also did not include the many cases in which judges used or discussed slippery slope reasoning without giving it a metaphorical name. As Schauer points out, "the opinions in which ... phrases [like 'slippery slope'] are used are but a thin slice of all the cases in which arguments in slippery slope form are employed." Schauer, supra note 1 , at 362 , n.10. Allusions and references to the slippery slope form of argument thus seem common in judieial opinions. It should be noted, however, that judges frequently discuss SSAs for the purpose of criticizing them rather than for the purpose of defending them.

118. 491 U.S. 397, 417 (1989).

119. See id. at 399.

120. Id. For discussion of the larger flag burning controversy of which Texas v. Johnson was a significant aspect, see RoBERT JUSTIN GOLDSTEIN, BURNING THE FLAG (1996). 
Court of the United States affirmed the Texas Court of Criminal Appeals' reversal of Johnson's conviction, ${ }^{121}$ holding that Johnson's act of burning the flag was expressive conduct within the protection of the First Amendment. ${ }^{122}$

Writing for the majority, Justice Brennan discussed Schact $v$. United States, ${ }^{123}$ in which the Court invalidated a federal statute that permitted an actor portraying a member of one of the Armed forces to "wear the uniform of that armed force if the portrayal does not tend to discredit that armed force." 124 The Schact Court stated that this proviso "leaves Americans free to praise the war in Vietnam but can send persons ... to prison for opposing it." 125 Schact thus held that this proviso "cannot survive in a country which has the First Amendment." ${ }^{26}$

Justice Brennan then stated in Johnson that

[w] perceive no basis on which to hold that the principle underlying our decision in Schact does not apply to this case. To conclude that the government may permit designated symbols to be used to communicate only a limited set of messages would be to enter territory having no discernible or defensible boundaries. Could the government, on this theory, prohibit the burning of state flags? Of copies of the Presidential seal? Of the Constitution? In evaluating these choices under the First Amendment, how would we decide which symbols were sufficiently special to warrant this unique status? To do so, we would be forced to consult our own political preferences, and impose them on the citizenry, in the very way that the First Amendment forbids us to do. ${ }^{127}$

This passage contains a clear example of slippery slope reasoning: It suggests that upholding the statute could lead to a series of other prohibitions, until the Court finally reaches some objectionable result.

Walton says that this argument appears to be an arbitrary result SSA because it holds that taking the first step on the slope would "lead to a series of unclear or arbitrary decisions about what to include." ${ }^{128}$ However, Justice Brennan also stated that in order to make such decisions, judges would end up consulting their own political preferences, which he thought would constitute a violation of the First Amendnent. Since this result is objectionable in itself, Justice Brennan may be interpreted as making a horrible result SSA.

121. See Johnson v. State, 755 S.W.2d 92 (1988), aff'd Texas v. Johnson, 491 U.S. 397 (1989).

122. See Johnson, 491 U.S. at 405-06.

123. 398 U.S. 58 (1970).

124. Id. at 60 (quoting 10 U.S.C. $\S 722(\mathrm{f})(1952)$ ).

125. Id. at 63 .

126. Id.

127. Johnson, 491 U.S. at 417 (citing Carey v. Brown, 447 U.S. 455, $466-67$ (1980)). For helpful discussion of this SSA and similar SSAs, see WALTON, supra note 4, at 267-77.

128. WALTON, supra note 4, at 270. 
It is also unclear whether Justice Brennan's argument is an empirical SSA or a rational grounds SSA. Insofar as he predicted that upholding the statute in Johnson would lead judges to impermissibly consult their political preferences, his argument is an empirical one. But if he was instead making the more principled point that upholding the statute would leave courts with no defensible basis on which to overturn other, more questionable statutes, his argument is of the rational grounds variety. It is therefore hard to pin down exactly what Justice Brennan found objectionable about stepping on the relevant slippery slope.

This sort of problein is common to many of the SSAs that people use in adjudication. Justice Brennan at least mentioned other possible steps on the slope: banning the burning of state flags, the Presidential seal, and the Constitution. In addition, he gave us some idea of what is supposedly objectionable about stepping on the slope; he suggested that doing so could either lead judges to impermissibly consult their own political preferences, or leave them with no defensible basis for resisting further restrictions on free speech. Frequently, however, those SSAs that people invoke in adjudication tend to be much more sketchy: Proponents of such arguments sometimes tell us very little about the steps they think the slope might contain or about why it would be objectionable to step on it.

But lack of clarity as to the sort of SSA a person means to invoke is not an insurmountable problem. We can simply analyze whether each of the possible slippery slope objections discussed in Part II provides a reason for resisting the practice under consideration.

This Part relies on the distinction between rational grounds SSAs and empirical SSAs. It argues that the concerns about arbitrariness and rational defensibility that underlie rational grounds SSAs are generally unfounded, but that SSAs that rely on empirical predictions can be valid. It then examines some of the factors that can help to fuel slides down empirically slippery slopes and makes some general remarks regarding the evaluation of einpirical SSAs. Because numerous factors can be relevant to evaluating empirical SSAs, this Part argues that we can make no sweeping generahzations regarding the strength of such arguments as a class. This Part does, however, provide general guidelines for evaluating enipirical SSAs. It concludes by discussing some of the roles that SSAs can play in judicial decision making.

\section{A. Concerns Relating to Arbitrariness and Rational Defensibility}

As discussed above, judges are often concerned with drawing nonarbitrary, rationally defensible lines. ${ }^{129}$ A number of considerations may underlie this concern. First, judges may be concerned about faimess. If

129. See supra note 112 and accompanying text. 
there are no significant differences between $A$ and $m$, and we already allow $A$, a judge nuay think that it would be unfair to those who would benefit from an allowance of $m$ to refuse to allow it. Second, a judge may be concerned about the integrity of the judicial system. ${ }^{130}$ As Ronald Dworkin suggests, it is desirable to have a coherent, consistent body of case law because this gives our legal systen integrity. ${ }^{131}$ If there are no relevant differences between $A$ and $m$ and the case law allows $A$ but prohibits $m$, it is arguable that such integrity is lacking.

This Section argues that the concerns about arbitrariness and rational defensibility that underlie rational grounds SSAs are generally unfounded. In some cases, there may be a non-arbitrary stopping place along the slope. To evaluate this claim, however, we need to spell out the steps on the slope in some detail and attempt to discern whether we can draw a non-arbitrary line upon it. To use this line of attack, we may need to examine the possible steps on the relevant slope with great scrutiny. This will often entail developing the argument to a greater degree than do the proponents of the SSA themselves.

But a more general critique can be made of rational grounds SSAs: Lines that contain an element of arbitrariness can still be rationally defensible. Even if we grant that there is no totally non-arbitrary stopping place along the slope, it does not follow that there would be no rational basis for allowing one case and refusing to allow the successive case. The focus of this Section will be on this critique, because it offers us a general way of dismissing the claims of most-if not all-rational grounds SSAs.

\section{Rational Grounds SSAs and the Abortion Debate}

As Part II discussed, one could argue that because of the lack of significant differences between fetuses and new-born babies at any two successive points of their development, allowing abortion at one stage of fetal development would leave us with no rational grounds for refusing to allow it at the next stage, and then the next, and then still the next, until we finally would have no rational grounds for refusing to allow infanticide. ${ }^{132}$ This argument holds that because there is no non-arbitrary stopping place along the slope, any line that we draw upon it would be rationally indefensible. One could thus hold that conception is the only place at which a bright and defensible line can be drawn. ${ }^{133}$

130. See generally RONALD DwORKIN, LAw's EMPIRE 225-75 (1986) (discussing the importance of integrity in the law).

131. See id.

132. See supra notes 74-77 and accompanying text.

133. See, e.g., John T. Noonan, Jr., An Almost Absolute Value in History, in The MoralitY of ABORTION 1, 51-57 (John T. Noonan, Jr. ed., 1970) (arguing that conception is the only objectively based, non-arbitrary point at which to draw the line between humans and non-humans on the grounds that conception is the point at which a being receives a human genetic code). 
In support of this argument, one could say that the acquisition of various properties or capacities that we deem morally relevant does not happen in a single and distinct moment in time; instead, the acquisition of such capacities is a process. Some people argue, for example, that when a fetus becomes sentient, it acquires a moral status that it previously did not have. ${ }^{134}$ One could thus argue that the acquisition of sentience should be the dividing line between legally permissible and legally impermissible abortions. The acquisition of sentience, however, seems to be a process rather than something that happens in a single and distinct moment in time. ${ }^{135}$ One could also hold that once a fetus becomes viable, the state has an interest in protecting that fetus that it previously did not have. ${ }^{136}$ But like sentience, the acquisition of viability appears to be a process. ${ }^{137}$ Different fetuses also become fully viable at different times. ${ }^{138}$ Insofar as the acquisition of potentially morally relevant properties and capacities is a process, we arguably are unable to appeal to these properties to draw a bright line between those abortions that should be permitted and those that should not. One could thus argue that any line that we draw on the slope will contain at least an element of arbitrariness and that it will therefore be rationally indefensible.

But this argument is flawed: Even lines containing an element of arbitrariness can be rationally defensible. As Govier says, "[m]ost often, lines are drawn for some purpose; then the defense of drawing the line at one place rather than another can proceed with reference to this purpose, and to pertiment empirical considerations." ${ }^{139}$ One can consistently hold that a woman's right to decide what happens to her own body entails that abortion must be legally permissible at least at some stages of fetal development, and that we can draw the line between legally permissible and legally impermissible abortions at a stage of fetal development that at least

134. See, e.g., L.W. Sumner, ABORTION AND MORAL THEORY 128-60 (1981). For some problems with Sumner's views on the relationship between sentience and the (im)permissibility of abortion, see Mary Anne Warren, The Moral Significance of Birth, HYPATIA, Fall 1989, at 46, 51-52.

135. See SUMNER, supra note 134, at 146 ("[S]entience admits of degrees...."). See generally Clifford Grobstein, Science and the Unborn 33, 56, 124-25, 127-30, 135, 154-56 (1988) (discussing the acquisition of sentience in fetuses).

136. See Roe v. Wade, 410 U.S. 113, 163-64 (1973) ("With respect to the State's important and legitimate interest in potential life, the 'compelling' point is at viability."). In Planned Parenthood of Southeastem Pennsylvania v. Casey, 505 U.S. 833 (1992), the Supreme Court reaffirmed Roe's holding that a woman has a right to an abortion before her fetus becomes viable. See id. at 846 . However, the plurality also rejccted the trimester framework of Roe and replaced it with an undue burden analysis. See id. at 878 (plurality opinion).

137. See generally Noonan, supra note 133 , at 52 ("[T] here is considerable elasticity to the idea of viability.").

138. See id. (noting that fetuses become viable at different times); Warren, supra note 134, at 50 ("[V]iability is relative, among other things, to the medical care available to the pregnant woman and her infant.").

139. Govier, supra note 38 , at 308-09. 
roughly correlates with the acquisition of a property or capacity that we deem morally significant.

Jonathan Glover also argues that the "claim that cut-off points with an element of arbitrariness cannot be justified seems mistaken." $140 \mathrm{He}$ approvingly quotes Father John Ford, who holds that it is "'a fairly common fallacy in legal and moral argumentation to conclude that all is lost because there is a field of uncertainty to which our carefully formulated moral principles cannot be applied with precision." "141 In order to illustrate why this is a fallacy, Glover asks us to consider the case of speed limits. ${ }^{142} \mathrm{He}$ says that a defender of a rational grounds SSA may "argue that we should either ban cars altogether or else allow driving at any speed anywhere. For how can a speed limit of thirty miles an hour possibly be defended as better than one of twenty-nine or thirty-one miles an hour?"143 Glover then argues that

The point that, in terms of safety, there may be no discriminable difference between two speed limits that vary by one mile an hour is an obviously feeble one. Suppose that the snuallest discriminable difference of safety is between speed limits differing by five miles an hour. A limit of thirty is safer than one of thirty-five. This shows that it is not permissible to continue to add sub-threshold amounts and to claim that they make no difference. The maximum claim that can be made is that it does not matter within four miles an hour where the limit is: it can vary, say, between twenty-eight and thirty-two. This then allows us to argue that blurred limits are less effective than precise ones, and so opt for any speed between twenty-eight and thirty-two. ${ }^{144}$

We thus should not conclude that because any line between legally permissible and legally impermissible abortions would contain an element of arbitrariness, it will be rationally indefensible. We niay be unable to draw a line that perfectly coincides with the acquisition of some morally relevant property or capacity, but blurred limits are less effective than precise ones. Blurred limits would create uncertainties in the law and may pose difficulties for enforcement. If a court decides that abortion at only some stages of fetal development must be permitted, it thus has good grounds for drawing a bright line between the time that abortion must and need not be permitted. In order to err on the side of caution, the court can even draw this line at a place before, or near the beginning of, the developmental stage at which most fetuses begin to acquire the property or properties that we deenı morally significant. Although such a line may

140. Glover, supra note 2, at 166 .

141. Id. (quoting Father John Ford).

142. See id.

143. Id.

144. Id. 
contain an element of arbitrariness, a desire both to allow some abortions and to prohibit the abortion of fetuses with morally relevant properties enables the court to rationally defend that line.

\section{Rational Grounds SSAs and the State Criminal Jury Size Cases ${ }^{145}$}

These points can be applied to other SSAs that people invoke in adjudication. Indeed, the Supreme Court appears to have accepted this line of reasoning in deciding the cases Williams $v$. Florida ${ }^{\mathrm{I46}}$ and Ballew $v$. Georgia. ${ }^{147}$ In Williams, the Court held that a refusal to impanel more than six jurors in a state criminal case did not violate the defendant's Sixth Amendment rights as applied through the Fourteenth Amendment. ${ }^{148}$ In his concurring opinion, Justice Harlan invoked a clear example of slippery slope reasoning by asking, "if 12 jurors are not essential, why are six?" 149 He then asked what would happen if a state "concludes that three jurors are adequate?"150 The clear implication of Justice Harlan's questions is that holding that six jurors are sufficient would leave the Court with no principled basis for rejecting the mipaneling of only five, four, or three jurors.

In writing for the Williams Court, Justice White responded to Justice Harlan's SSA by saying that this line of reasoning "suffers somewhat as soon as one recognizes that he can get off the 'slippery slope' before he reaches the bottom."151 Justice White stated that although the Williams case presented the Court with "no occasion ... to determine what minimun nuinber can still constitute a 'jury', ... we do not doubt that six is above that minimum." $" 152$

145. Many of the remarks of this Section derive from Schauer, supra note 1, at 379-80.

146. 399 U.S. 78 (1970).

147. 435 U.S. 223 (1978) (plurality opinion).

148. See Williams, 399 U.S. at 86 . For helpful discussion of Williams and other cases pertaining to the sizes of state criminal juries, see Robert H. Miller, Comment, Six of One is Not a Dozen of the Other: A Reexamination of Williams v. Florida and the Size of State Criminal Juries, 146 U. PA. L. REV. 621 (1998).

149. Williams, 399 U.S. at 126 (Harlan, J., concurring).

150. Id.

151. Id. at $91 \mathrm{n} .28$. The Supreme Court also made this point in Qualitex Co. v. Jacobson Products Co., 514 U.S. 159 (1995). At issue in Qualitex was "whether the [Lanham Act] permits the registration of a trademark that consists, purely and simply, of a color." Id. at 160-61. In holding that color alone can serve as a trademark, the Court rejected Jacobson's argument that "if one of many competitors can appropriate a particular color for use as a trademark, and each competitor tries to do the same, the supply of colors will soon be depleted." Id. at 168. This argument is of the slippery slope variety: It holds that allowing a trademark on one color could lead to a trademark on another, and then another, and then still another, until finally some competitor will face a state of affairs in which no colors are left, which would put the competitor at a serious disadvantage. In rejecting this argument, the Court noted that it could "prevent the anticompetitive consequences of Jacobson's hypothetical "color depletion' argument, when, and if, the circumstances of a particular case threaten 'color depletion." Id. at 170. Once again, the Court suggested that it could step off the slope before it got to the bottom.

152. Williams, 399 U.S. at 91 n.28. 
There are at least two ways to interpret Justice White's response to the relevant SSA. First, he could be asserting that there is some non-arbitrary stopping place on the slope, whether it be at six jurors, five, four, or even two or one. If this is the case, the Court would obviously have a principled basis for accepting a certain number of jurors but refusing to recognize a "jury" that contained fewer than that number: The Court could point to the relevant difference between those two numbers of jurors and hold that this difference justifies drawing a line between them. For example, if the Court held that the proper line is between two and one, it could state that two jurors are acceptable but a single juror is not because having a single juror would give that person too much power.

Assuming, however, that the Court would not be willing to accept only two jurors, it is difficult to see how there is some totally non-arbitrary stopping place along the slope. Having six jurors does not seem significantly different from having only five, which does not seem all that different from having four.

This leads to a second possible interpretation of Justice White's response to the relevant SSA: Justice White could be asserting that the lack of a totally non-arbitrary stopping place is not a significant problem. There may be a gray area in the spectrum of possible jury sizes between those that are clearly permissible and those that are not. We could interpret Justice White as saying that as long as the Court draws the line somewhere before (or im) that gray area, it has a rational basis for getting off the slope. The desire to give states leeway regarding how many jurors to impanel while also making sure that states do not impanel some number below the acceptable minimum would give the Court a rational basis for drawing the line where it did. Even if such a line contains an element of arbitrariness, these considerations make it rationally defensible.

Hindsight gives us grounds for preferring the latter interpretation. In Ballew, the Court made it clear that although six jurors are constitutionally sufficient, five are not. ${ }^{153}$ It stated, however, that it did "not pretend to discern a clear line between six members and five." 154 As Schauer notes, "[n]o one can maintain that there is anything natural or magical about the six/five distinction." "iss Although the line between six and five is rather arbitrary, it does not follow that it is rationally indefensible. The desire to prevent a slide toward allowing a clearly constitutionally insufficient number of jurors provided the Court with a rational basis for defending the line that it drew.

153. See Ballew, 435 U.S. at 228 (plurality opinion).

154. Id. at 239.

155. Schauer, supra note 1 , at 379. 


\section{Concluding Remarks}

We cannot infer that a line will be rationally indefensible simply because it contains an element of arbitrariness. A desire to allow one case and not allow objectionable cases further down the slope provides courts with a rational basis for defending even somewhat arbitrary lines. The concerns underlying rational grounds SSAs are thus unfounded.

It should be noted, however, that in some cases, not just any line will do. Suppose, for example, that the Court thinks that the state has a compelling interest in protecting fetal life only when the fetus becomes viable. If the Court presumes that fetuses become viable somewhere between the twenty-fourth and twenty-eighth weeks of their development, ${ }^{156}$ it would not be defensible for the Court to say that the state can prohibit abortions past the seventh week of pregnancy for the sake of protecting fetal life: Such a line would not be drawn in the correct area of the slope. This point, however, does not apply to those lines that are drawn in the correct area. Such lines can be rationally defensible, even if they are somewhat arbitrary.

It should also be noted that a slope's lack of a totally non-arbitrary stopping place can be conducive to an empirical slide down it. As Schauer suggests, even though judges need not be hesitant to draw at least some relatively arbitrary lines, they in fact often are. ${ }^{157} \mathrm{~A}$ continuum of closely related practices can thus help lead judges to allow cases further down the slope.

But whether judges will do so is an empirical question to which the clains of rational grounds SSAs can, by themselves, provide no answer. The next Section thus examines the empirical concerns that inay underlie people's invocations of SSAs.

\section{B. Empirical Concerns}

Schauer notes that in each case in which an SSA is made, "the opposing party could with equal formal and linguistic logic also make a slippery slope claim." "158 $\mathrm{He}$ thus argues that an SSA "depends for its

156. This is what the Court presumed in Roe v. Wade. 410 U.S. 113, 160 (1973).

157. See Schauer, supra note 1 , at 380 .

158. Id. at 381. In order to illustrate this point, Schauer asks us to imagine the following dialogue using the facts of Lynch v. Donnelly, 465 U.S. 668 (1984):

Objector: If you allow Pawtucket, Rhode Island, to erect a nativity scene on public property, then it is only one small step to allowing organized prayers and religious services on public property, and then the next step is involvement of public officials in those services, and then official endorsement of particular religious denominations, which is exactly what the establishment clause was originally designed to prevent. Defender: If you allow the courts to stop Pawtucket from erecting the nativity scene, then the next step is allowing the courts to prohibit any mention of religion at all, including studying the Bible as literature in schools and hanging Giotto paintings in publicly funded museums, and then the courts will prohibit any public official from mentioning religion, and before long the courts will even prohibit fire and police protection of church buildings. 
persuasiveness upon temporally and spatially contingent empirical facts rather than (or in addition to) simple logical inference."159 Numerous other commentators suggest that the strength of particular SSAs often rests on empirical considerations, such as the context in which the argument is invoked ${ }^{160}$ Philosophers, for example, frequently hold that rational grounds SSAs are bad arguments, while empirical SSAs can be valid. ${ }^{161}$ This Comment adopts the same position: The previous Section argued that rational grounds SSAs are unfounded; this Section argues that empirical SSAs can be sound. In addition, this Section both describes some of the factors that can help to fuel slides down empirically slippery slopes and provides some general guidelines for evaluating empirical SSAs. Because of the numerous different factors relevant to evaluating such argunents, this Section argues that we can make no sweeping generalizations regarding the strength of empirical SSAs as a class.

\section{Empirical SSAs Are Not Inherently Fallacious}

Unlike rational grounds SSAs, we cannot dismiss the claims of all empirical SSAs with a few general remarks. Empirical SSAs maintain that we should not allow $A$ on the grounds that allowing it would increase the likelihood of our allowing each successive case on the slope, until we finally reach some objectionable result. As Mayo points out, we all recogmize the risks of certain courses of action and routinely avoid these risks. ${ }^{162}$ He says that "[d]ieters are wise to resist the temptation of even just one dipped potato chip,... [and] warnings about the corrupting properties of cocaine strike us as legitimate." ${ }^{163}$ We know that acting in certain ways may set us down problematic paths as individuals; many of us thus try to avoid stepping on such paths in the first place. Just as individuals may set themselves on problematical paths by adopting certain courses of action, society may set itself on problematical paths by adopting certain policies, and courts may set themselves on problematical paths by making certain rulings. Empirical SSAs thus do not necessarily commit any fallacy. ${ }^{164}$

Schauer, supra note 1, at 381 . Schauer also notes that "[i]n the context of criminal procedure it is indeed common for slippery slope arguments to be made on both sides. Appeals to the danger cascs of uncontrolled police power on the one hand, or of police shacklcd by procedural requirements on the other, are presented with some regularity." Id. at 382 n.55.

159. Schauer, supra note 1 , at 381 .

160. See, e.g., LAMB, supra note 30, at 1-2; WALTON, supra note 4, at 151-53; Williams, supra note 38, at 185; Rudinow, supra note 104, at 28 .

161. See, e.g., GLover, supra note 2, at 166-67; Holtug, supra note 8, at 403-04; Rachels, supra note 40 , at $69-71$.

162. See Mayo, supra note 18 , at 88 .

163. Id.

164. Some empirical SSAs, however, make claims that are so strong and indefensible that the arguments appear fallacious. For example, Vincent $\mathrm{E}$. Barry defines the fallacy of the slippery slope as "the fallacy of assuming an action will inevitably lead to a consequence when, in fact, there is no such inevitability." VINCENT E. BARRY, PRActical Logic 132 (2d ed. 1980) (emphasis added). Barry says 


\section{Factors that Can Help Fuel Slides down Empirically Slippery Slopes}

But to say that empirical SSAs are not inherently fallacious does not mean that all such arguments are good ones. Non-fallacious arguments can still be extremely weak. Numerous inquiries must be made in attempting to separate the good empirical SSAs from the bad ones. One important task is to determine how plausible it is to suppose that allowing $A$ will lead to a slide down a slippery slope. This Section describes some of the factors that can help lead to such slippage.

\section{a. Precedents and Continuums}

As discussed above, the notion of precedent plays a large role in the American legal system. ${ }^{165}$ In addition, the slippery slope itself will often take the form of a continuum: Each case on the slope will tend to differ from its successive case only incrementally. ${ }^{166}$ These two considerations make the court system particularly conducive to slides down empirically slippery slopes.

Such slippage can result if a court is confronted with a succession of cases, each of which differs from the previous case only incrementally. The court may take its decision to allow $A$ as a precedent for allowing $m$; it may then take its decision to allow $m$ as a precedent for allowing $n$. The similarities between successive cases on the slope, combined with the role that precedent plays in judicial decision making, could lead a court to allow more and more.

Judges sometimes resist this line of reasoning. For example, in Panhandle Oil Co. v. Mississippi ex rel. Knox, ${ }^{167}$ the Court ruled that a state

that someone who commits this fallacy does not understand what a cause is: Even if $A$ causes $B$, it does not necessarily follow that we cannot prevent $B$ from occurring if we allow $A$. See id. at 102 . For an example of an SSA that Barry would classify as fallacious, consider the following argument:

This Court should not recognize a right to die for competent patients who voluntarily request

help in dying and are terminally ill on the grounds that doing so would necessarily lead some

future court to allow physicians to kill those patients who are not terminally ill. This in turn

would necessarily lead some court to allow the killing of patients who are not competent, until finally some court will inevitably decide to allow involuntary euthanasia.

This argument is clearly a bad one; the claims that it makes are much too strong. Even if judicial recognition of a right to die did lead to the progression that the argument describes, there would seem to be nothing necessary or inevitable about this course of events. Some future court could easily decide to toe the line at a certain place and not allow further steps down the slope. The above SSA is thus probably so bad that it deserves to be called fallacious.

But Barry's characterization of the fallacy may be a straw person: Empirical SSAs typically make claims about what is likely to happen if we allow $A$, rather than about what will necessarily or inevitably happen as a result of allowing it. People who use such arguments will sometimes even provide evidence to back up their predictive claims. Empirical SSAs thus should not be deemed fallacious as a class: Legal decisions do have consequences, and in some cases, it may be reasonable to think that the taking of one step can help lead a court to take a series of other steps.

165. See supra Part III.B.

166. See supra Part I.B.

167. 277 U.S. 218 (1928). 
tax on gasoline was void under the Constitution as applied to certain instrumentalities of the federal government. ${ }^{168}$ In dissent, Justice Holmes famously remarked that "[t]he power to tax is not the power to destroy while this Court sits." ${ }^{\prime 69}$ Justice Holmes thus implicitly stated that allowing the tax at issue would not lead to a series of other taxes, with the final result of the taxes being the destruction of the federal government. As Justice Holmes's remarks illustrate, a Supreme Court Justice can maintain that there is no danger of sliding to some objectionable outcome while that Court is in place. In support of this point, the Court could argue that even if any line that it draws on the slope would contain an element of arbitrariness, some such lines will still be rationally defensible. ${ }^{170}$

Justice Holmes's statement, however, also implicitly concedes that the composition of the Court will change. As Schauer says,

Even oversimplified generalizations like "the Warren Court" and "the Burger Court" remind us that the character of an institution changes with the changing identity of its component individuals. A lawyer arguing in slippery slope form before the Supreme Court is often claiming, albeit in a veiled manner, that this Court, for all its wisdom, should not depend on that wisdom being perpetuated in a differently constituted Court. The fears of the slippery slope claimant are thus not assuaged by the assurance that the danger case will not be permitted "while this Court sits."171

Wibren van der Burg illustrates one way in which the decisions of different judges in different cases can result in slippage:

Judge $\mathrm{X}$ may think that $n$ and $\mathrm{B}$ are similar and that the line should be drawn between $m$ and $n$, while Judge $Y$ thinks that the line should be drawn between $n$ and $\mathrm{B}$. If Judge $\mathrm{Y}$ upon this basis has accepted $n$, then Judge $\mathrm{X}$, respecting the precedent created by $\mathrm{Y}$, will make the further step toward the acceptance of B. Though neither Judge $\mathrm{X}$ nor Judge $\mathrm{Y}$ would have made the step from $\mathrm{A}$ to $\mathrm{B}$ directly, their combined activity leads to the acceptance of B. ${ }^{172}$

The fact that different judges will think that lines should be drawn in different places can thus help lead the judicial system to move further and further down the slope.

These considerations, however, do not suggest that there is anything necessary or inevitable about such a slide. Different judges may agree

168. See id. at 222.

169. Id. at 223 (Holmes, J., dissenting); see also School Dist. of Abington Township v. Schempp, 374 U.S. 203, 308 (1963) (Goldberg, J., concurring) ("It is of course true that great consequences can grow from small beginnings, but the measure of constitutional adjudication is the ability and willingness to distinguish between real threat and mere shadow.").

170. See supra Part IV.A.

171. Schauer, supra note 1, at 374-75 (footnotes omitted).

172. van der Burg, supra note 29 , at 50. 
about where the line should be drawn, or a judge deciding a subsequent case could recognize that even though the line between, for example, $m$ and $n$ is somewhat arbitrary, it still should be drawn in order to prevent further slippage down the slope. As Schauer notes, however, judges may be hesitant to draw lines containing elements of arbitrariness, even if they have good reasons for doing so. ${ }^{173}$

A court could help to alleviate this problem by imdicating in dicta that its holding that allows $A$ has no implications for cases involving $o$ and $p$. Indeed, the court could even go so far as to explicitly express its disapproval of allowing such cases. While such dicta would not bind future courts, it would at least give them some authority for resisting $o$ and $p$ if they deem this appropriate. Such dicta may thus undercut a future court's concerns about arbitrariness: It can say that the court that allowed $A \operatorname{did}$ not mean to allow $o$ and $p$, and that drawing the line at $o$ and $p$ is thus rationally defensible.

In addition, the case law often will not progress in the way that proponents of SSAs envision. For example, after a court decides to allow $A$, the next case it decides may deal with $p$ or $o$ rather than with $m$. Although there may be no bright line between $A$ and $m$, there may be obvious differences between $A$ and $p$. The court deciding the case involving $p$ can thus state that the case allowing $A$ does not serve as a precedent.

In sum, stare decisis, combined with a continuum of closely related cases, can be conducive to a slide down a slippery slope. These factors do not, however, inevitably lead to slippage. While proponents of SSAs often rely on the notions of precedents and continuums, their SSAs would be strengthened if they discuss other factors that would encourage courts to slide down a slippery slope.

\section{b. Vague and Indeterminate Terms}

SSAs often make use of the idea that certain key terms are vague or indeterminate. ${ }^{174}$ As discussed above, SSAs that oppose allowing abortion often make use of the vagueness of concepts such as "personhood."175 Similarly, SSAs that oppose allowing human gene therapy frequently play upon the vagueness of the concepts "defect" or "disorder."176

Judges' uses of vague terms can also be conducive to a slide down a slippery slope. If one judge applies a vague term to $A$, another may then decide to apply that term to $m$.

173. See Schauer, supra note 1, at 380 .

174. See supra Part II.A.1.

175. See text accompanying notes $74-75$.

176. See Rifkin, supra note 25, at 232; Whether to Make Perfect Human Beings, supra note 25. But see Holtug, supra note 8, at 410 (agreeing with proponents of SSAs that certain key concepts are vague, but arguing that this does not provide us with sufficient grounds for resisting human gene therapy). 
Debates concerning active voluntary euthanasia and physicianassisted suicide are rife with vague terms ${ }^{177}$ Even if there are good reasons for allowing active voluntary euthanasia or physician-assisted suicide for "competent" patients who "voluntarily" request it, who are "terminally ill," and who are suffering "intolerable pain," one could point out that these terms are vague. This vagueness could lead one to argue that judicial recognition of a right to die for patients who meet these criteria could lead to a slide down a slippery slope. ${ }^{178}$

Susan R. Martyn and Henry J. Bourguignon criticize decisions by the Ninth and Second Circuits, ${ }^{179}$ each of which "would recognize a constitutional right to physician-assisted suicide only for a competent patient who voluntarily seeks help in dying, is terminally ill, is suffering intolerable pain, and receives assistance from a physician in dying." 180 Martyn and Bourguignon argue that these concepts are indeterminate and that the "fragile and permeable line [drawn by the Ninth and Second Circuits] fails to prevent involuntary assisted suicide and euthanasia for a large number of vulnerable patients." 181 While the Supreme Court reversed the decisions of the Ninth and Second Circuits in Washington v. Glucksberg ${ }^{182}$ and Vacco v. Quill, ${ }^{183}$ respectively, Martyn and Bourguignon's remarks illustrate some important points. Indeed, the Court appeared to be at least somewhat sympathetic to the relevant SSAs in deciding both cases. ${ }^{184}$

This Section examines the indeterminacies of terms such as "voluntary" and "terminally ill." It argues that such indeterminacies alone do not necessitate a slide down a slippery slope. People frequently remain steady in their application of vague terms. In order for slippage to be likely, there must be reasons other than mere indeterminacy to fear that the terms will be expanded to include more and more cases.

177. See, e.g. , LAMB, supra note 30, at 61-75; Doerflinger, supra note 11, at 16, 18; Susan $R$. Martyn \& Henry J. Bourguignon, Physician-Assisted Suicide: The Lethal Flaws of the Ninth and Second Circuit Decisions, 85 CALIF. L. Rev. 371, 373, 390-410 (1997).

178. Washington v. Glucksberg, 521 U.S. 702 (1997), held that "the asserted 'right' to assistance in committing suicide is not a fundamental liberty interest protected by the Due Process Clause." Id. at 728. It is possible, however, that some future Court will recognize a right to die. It is also possible that some state supreme courts will find this right to be protected by their state constitutions.

179. See Quill v. Vacco, 80 F.3d 716 (2d Cir. 1996), rev'd 521 U.S. 793 (1997); Compassion in Dying v. Washington, 79 F.3d 790 (9th Cir. 1996) (en banc), rev'd sub nom. Washington v. Glueksberg, 521 U.S. 702 (1997).

180. Martyn \& Bourguignon, supra note 177 , at 390.

181. Id.

182. 521 U.S. 702 (1997).

183. 521 U.S. 793 (1997).

184. See supra note 14. 


\section{i. The Concepts "Voluntary" and "Competent"}

To begin with, terms like "voluntary" and "competent" are indeterminate. Even if there are clear cases of people who express a voluntary, informed, rational, and competent desire to die, ${ }^{185}$ it is not clear where we could draw the line between these cases and other cases that are less comfortably identified as "voluntary" euthanasia or "voluntary" physicianassisted suicide. As Martyn and Bourguignon note, many people who request suicide are under the influence of drugs or beset with anxious feelings. ${ }^{186}$ Some also "entertain rescue fantasies," cally depressed. ${ }^{188}$ All of these factors may make a patient's decision to die less than fully voluntary.

At the same time, however, we would not want to require that a choice be absolutely uninfluenced by other considerations in order for it to be voluntary. If we did, no choice would be deserving of this title. For example, one may decide to attend law school because of a less than ideal job market in another field. But we would not want to say that this outside influence alone renders one's decision involuntary.

Given these considerations, any useful definition of "voluntary" will contain subjective elements: We must decide how much influence we will tolerate in a "choice" before saying that it is no longer "voluntary." But if this is the case, we can draw no bright, objectively-based line between choices that are voluntary and "choices" that are not. Martyn and Bourguignon thus conclude that "the line the Ninth and Second Circuits attempt to draw at voluntary requests is no firm line at all." 189

\section{ii. The Concept "Terminally Ill"}

Similar points can be made about the concept "terminally ill." Richard Doerflinger describes some of the ways in which the meaning of this term both can be, and already has been, expanded. ${ }^{190} \mathrm{He}$ states:

At the Hemlock[] [Society's] 1986 convention, [the] Dutch physician Pieter Admiraal boasted that he had recently broadened

185. It may be unclear how many such cases there would be. As Kamisar says,

[I] the adult patient really in a position to concur? Is he truly able to make euthanasia a "voluntary" act? There is a good deal to be said, is there not, for Dr. Frohman's pithy comment that the "voluntary" plan is supposed to be carried out "only if the victim is both sane and crazed by pain."

Kamisar, supra note 2, at 985-86.

186. See Martyn \& Bourguignon, supra note 177, at 393 .

187. Id.

188. See id. at 393-94; see also Glucksberg, 521 U.S. at 730 ("Those who attempt suicideterminally ill or not-often suffer from depression, or other mental disorders.") (citations omitted). In Glucksberg, the Court also stated that "[r]esearch indicates ... that many people who request physician-assisted suicide withdraw that request if their depression and pain are treated." Id.

189. Martyn \& Bourguignon, supra note 177, at 396.

190. See Doerflinger, supra note 11 , at 18. 
the meaning of terminal illness in his country by giving a lethal injection to a young quadriplegic woman-a Dutch court found that he acted within judicial guidelines allowing euthanasia for the terminally ill, because paralyzed patients have difficulty swallowing and could die from aspirating their food at any time. ${ }^{191}$

Doerflinger also argues that "[t]he medical and legal meaning of terminal illness has already been expanded in the United States by professional societies, legislatures, and courts in the context of so-called passive euthanasia." 192 He says that,

A Uniform Rights of the Terminally Ill Act proposed by the National Conference of Commissioners on Uniform State Laws in 1986 defines a terminal illness as one that would cause the patient's death in a relatively short time if life-preserving treatment is not provided - prompting critics to ask if all diabetics, for example, are "terminal" by definition. ${ }^{193}$

As Martyn and Bourguignon argue, "[g]iven the many different interpretations to which the characteristic is subject, 'terminally ill' does little to secure the line drawn by the Ninth and Second Circuits." 194

\section{iii. Concluding Remarks}

As the above discussion illustrates, indeterminacies in key terms can increase the likelihood of slides down slippery slopes. Judges may disagree about how to apply such terms; if one decides to apply a vague term to $m$, another may decide to apply it to $n$. It is also possible that people who want to see us move further down the slope will exploit the vagueness of such terms in an attempt to get the judiciary to take further steps. Suppose, for example, that some future legislature passes a statute that allows human gene therapy only for the purposes of curing genetic "defects." Companies in the biotechnology industry who would profit from the use of this technology may bring a flurry of lawsuits attempting to expand the applications of this vague term. ${ }^{195}$ Similarly, physicians who seek fame (or have more sinister motives) could attempt to bring lawsuits to expand judicial applications of terms such as "voluntary" and "terminally ill" so that physicians will be allowed to help their patients die in more and more cases.

Of course judges could attempt to define vague terms more precisely im order to help prevent a slide. For example, a court could mention in dicta situations in which it would not view a patient as "terminally ill" or a

\footnotetext{
191. Id

192. $I d$.

193. Id.

194. Martyn \& Bourguignon, supra note 177, at 398.

195. See generally ANDREw Kimbrell, The Human Body SHOP 151 (1993) (explaining how such companies have already attempted to exploit indeterminacies in concepts such as "disorder" and "defect" for the sake of increasing profits).
} 
request for assistance in dying as "voluntary." Such remarks would not be binding on courts deciding future cases, but they would at least give the future courts some authority for resisting further steps down the slope.

As Schauer points out, however, "[b]oth our laws and our minds are limited-it is not practical and perhaps not even possible to describe fully those distinctions we can envision clearly in our heads."196 While judges may be able to mention some of the cases they mean to exclude in using vague terms, they will not be able to mention all of them. Indeed, sometimes a judge may not even consider a case that, if it were brought to her attention, she would want to exclude. An inability to clearly delimit all of the cases to which a decision does not apply can increase the likelihood of a given decision leading to a shide down a slippery slope.

Schauer also argues that linguistic imprecision is sometimes desirable: Judges may wish to use imprecise language to gain "the long-run flexibility that enables us to accommodate the unexpected." "For example, any case that applies a "reasonableness" standard relies on imprecise language: Courts do not appear to hold that there is a definition of "reasonable" that holds for all situations, places, and times. Discerning the contours of what is and is not "reasonable" requires an act of judgment. As Schauer says, however, the "advantageous flexibility" of using imprecise language "also increases the slippery slope risk."198

While the use of vague and indeterminate terms can be conducive to a slide down a slippery slope, such terms do not necessitate slippage. People frequently remain steady in their applications of vague terms. For example, terms such as "tall," "short," and "bald" are all vague, 199 but the mere vagueness of such terms does not appear to have led us to gradually apply them to more and more cases. To have good grounds for resisting a particular ruling because it would contain vague terms, courts should thus have some independent reason for believing that future courts will extend the applications of those terms to encompass problematical practices. Proponents of SSAs should provide such reasons to the courts and not rest their cases merely on vagueness alone.

Often, however, there will be reasons for fearing that vague terms will be applied to more and more cases. For example, some people may want to see us slide down the slope, and they may bring lawsuits in an effort to expand the meaning of vague terms. If organized litigation campaigns encourage the broadening of vague terms, slippage may be difficult for courts to resist.

196. Schauer, supra note 1 , at 371 .

197. Id. at 372 .

198. Id. at 373 .

199. Such terms both can be and have been used to construct paradoxes with the same structure as the sorites paradox. For discussion of the sorites paradox, see infra notes $78-80$ and accompanying text. 


\section{c. The Context in Which an SSA Is Invoked}

As discussed above, the context in which someone invokes an SSA can bear on that argument's strength. ${ }^{200}$ This Section discusses several ways in which this consideration is relevant to empirical SSAs invoked in adjudication. If, for example, we think that the judiciary has, or is likely to come to have, views that are conducive to a slide down a particular slippery slope, the relevant SSAs will have more force than they otherwise would have. In addition, if it seems likely that powerful or influential segments of society would try to "push" us down the slope, slippery slope fears also have greater validity.

For an example of a way in which the climate of judicial opinion may be conducive to a slide down a slippery slope, consider President Reagan's attempt to "stack" the federal judiciary with people who would either "chip away" at or overrule Roe v. Wade, ${ }^{201}$ and thus restrict or eliminate a woman's right to abort a non-viable fetus. ${ }^{202}$ Other things being equal, an SSA that held that we should resist a particular restriction on a woman's right to an abortion, on the grounds that such a restriction would be likely to lead to further erosions of that right, would have more force if it were made in this context than if it were made in a context in which the President only appointed judges with more permissive views on abortion. Attempting to discern the climate of opinion regarding a particular issueboth among the judiciary and among our political leaders-is thus relevant to evaluating particular empirical SSAs.

In addition, judges themselves are members of society who are susceptible to social forces. Although judges can act as a check on majoritarian sentiment, they can also be influenced by public opinion. A climate of public opinion in favor of a slide down a slippery slope could thus affect members of the judiciary.

Consider the rising costs of health care. In 1994, Battin estimated that about fourteen percent of the United States's gross domestic product was spent on health care; about thirty percent of this figure went toward the care of people in the last six months of their lives. ${ }^{203}$ The amount of money the United States spends on health care is also "steadily on the rise." ${ }^{\text {"2t }}$ It is possible that the cost of keeping certain people alive could eventually help lead to some sort of social consensus that we are "wasting money" by

200. See supra Part III.

201. 410 U.S. 113 (1973).

202. See, e.g. , TriBE, supra note 75, at 17 ("President Reagan ... carried out the right-to-life plan to alter the face of the federal judiciary. The most significant litmus test for would-be judges on the federal Court of Appeals or the Supreme Court under Reagan was opposition to Roe v. Wade." (citing Herman Schwartz, Packing the Courts 42, 60-62, 64-66, 78, 84-85, 87-88, 100-01 (1988))).

203. See BATtin, supra note 7, at 13.

204. FURROW ET AL., supra note 22, at 718 ("We spent four times as much on health care in 1995 as we did in 1980."). 
doing so. ${ }^{205}$ If this view filters into the judiciary, the risks that a decision recognizing a right to die would lead to a slide down a slippery slope would be greater than they otherwise would be. ${ }^{206}$

As suggested above, people with power and influence also may stand to gain economically from taking steps down the slope. ${ }^{207}$ In addition, they may think that it is better from a moral point of view to take such steps. Suppose, for example, that some relatively influential group favored legalizing active voluntary euthanasia or physician-assisted suicide and also thought that strong moral arguments can be made for allowing certain forms of nonvoluntary euthanasia. We would then have some reason for thinking that the recogmition of a right to die would lead this group to bring a series of lawsuits in an attempt to extend the cases in which a physician could permissibly kill a patient or assist her in dying.

In evaluating SSAs invoked in adjudication, it is therefore helpful to pay attention not only to the climate of judicial opinion regardimg a certain issue, but also to the wider social forces that may help to propel us (or prevent us from sliding) down a slippery slope. Both the climate of judicial opinion and wider social forces can be relevant to evaluating particular empirical SSAs.

\section{d. Psychological Considerations}

Psychological considerations can also fuel slides down slippery slopes. As suggested above, aspects of judicial psychology may make judges hesitant to draw lines that appear arbitrary, even if they have good grounds for doimg so. ${ }^{208}$

Other possible psychological phenomena can help to fuel such slides. Humans arguably have a tendency to psychologically assimilate closely related cases. This tendency could lead us to gradually allow cases further down the slope if we step on it in the first place. If, for example, $A$ does not differ all that much from $m$ and we allow $A$, we may psychologically assimilate $A$ and $m$ and think that we should allow $m$ as well. If we proceed in this way long enough, we may eventually come to allow cases that we would now regard as deplorable.

One possible psychological phenomenon of relevance here is cognitive dissonance. ${ }^{209}$ Cognitive dissonance is the experience of

205. Cf. Washington v. Glucksberg, 521 U.S. 702, 784 (1997) (Souter, J., concurring) ("Physicians, and their hospitals, have their own financial incentives, too, in this new age of managed care.")

206. For reasons for thinking that this will not happen, see infra note 269.

207. See supra note 195 and accompanying text; see also infra Part IV.B.3 (describing a way in which corporate entities have already sought to lead us down a slippery slope).

208. See supra note 173 and accompanying text.

209. My thinking on the possible relationship between cognitive dissonance and slippery slopes has benefited greatly from discussions with Kim Weaver, who also pointed me to relevant studies and discussions. The classic work in cognitive dissonance theory is LEON FESTINGER, A THEORY OF 
self-inconsistency: When we act in ways that are contrary to our values or our attitudes, we experience psychological discomfort and will attempt to eliminate this discomfort by changing either our behavior or our attitudes. ${ }^{210}$ Since our present attitudes are presumably easier to change than our past behavior, we may have some tendency to try to eliminate our psychological discomfort by changing our present attitudes.

At least one study suggests that altering our attitudes toward one case will lead to changes in our views on closely related cases. ${ }^{211}$ Michael R. Leippe and Donna Eisenstadt conducted an experiment that urged white college students to write essays advocating giving more scholarship money to black students, at the expense of the money available to white students. ${ }^{212}$ Under certain conditions (such as when the students were led to believe that the essays would be read by high-ranking administrators in charge of the scholarship money, and the students were asked to put their names and student numbers on the essays), students who fully complied with the study tended to have different attitudes after writing the essays. But not only did they come to have more favorable attitudes toward scholarship money for black students; the students also had more favorable attitudes regarding other issues related to black people. ${ }^{213}$ For example, the students became more accepting of propositions such as, "blacks face unfair obstacles and can succeed and enrich society if these obstacles are removed."214

Many of the students in the study presumably experienced cognitive dissonance because they wrote essays that were contrary to their beliefs. This then led them to alter their beliefs so that their beliefs better coincided with the views they expressed in their essays. What changed, however, was not merely the students' attitudes toward matters they explicitly discussed in their essays, but their views on related matters as well. One possible explanation for this is that the students implicitly perceived that for their belief systems to form coherent wholes, they would have to revise other aspects of their belief systems. For example, the students may have implicitly realized that their new attitudes on scholarship money for black students were in tension with their previous beliefs regarding the barriers that black people face and the contributions that black people can make to

Cognitive Dissonance (1957). Other helpful discussions include Understanding Social Psychology chs. 3-4 (Joel Cooper \& Stephen Worchel eds., 1979), and Michael R. Leippe \& Donna Eisenstadt, Generalization of Dissonance Reduction: Decreasing Prejudice Through Induced Compliance, 67 J. PERSONAlity \& Soc. Psychol. 395 (1994).

210. See, e.g., Andrew J. Elliot \& Patricia G. Devine, On the Motivational Nature of Cognitive Dissonance: Dissonance as Psychological Discomfort, 67 J. Personality \& Soc. Psychol. 382 (1994); Leippe \& Eisenstadt, supra note 209, at 395-396.

211. See Leippe \& Eisenstadt, supra note 209.

212. See id.

213. See id. at $395,398-411$.

214. Id. at 409-11. 
society if these barriers are removed. In order to make their belief systems form more coherent wholes, the students may have revised their views on other related issues.

Leippe and Eisenstadt's study supports the point that accepting one case can lead to changes in our views on other, related cases. Suppose that a judge is hesitant to allow case $A$, but realizes that allowing $A$ best comports with a given statute or existing precedent. Dissonance theory suggests that voting in favor of allowing $A$ may lead to changes in the judge's views on $A$. The fimdings of Leippe and Eisenstadt suggest, however, that the judge's views on other, closely related cases may undergo changes as well. In order for her views to form a more coherent whole, the judge inay change not only her views on $A$, but also her views on closely related cases like $m$ and $n$.

It would be desirable, however, to have more research performed on these matters. For exampIe, it would be helpful to have a better understanding of the conditions under which accepting one case is likely to lead to changes in our views on similar cases. It would also be desirable to have a more thorough understanding of how similar cases must be (or how similar we must perceive them to be) in order for it to be likely that such changes will take place. But until these issues are studied in more detail, we should keep in mind that there may be at least some psychological pressures to move down certain slippery slopes.

\section{e. Corruption of the Decision-Making Process}

Other closely related factors can also lead to such slides. First, going through some process may change our views of that process. By allowing each successive case on a slope, judges' views on the law may begin to change in ways that lead them to neglect their possible hesitancy to step on the slope in the first place. Second, allowing some practice could lead to a shift in our norms regarding when uses of that practice are appropriate. Third, certain decisions may becoine landmarks-cases we use to "chart our course to future decisions." 215 If a case is viewed as a landmark rather than as a mere exception to soine existing rule, the course of future decision making inay radically change. While critics of the status quo may regard such a change as progress, proponents of the relevant SSA are likely to view it as corruption.

\section{i. Going Through a Process May Alter Our Views of It}

Numerous judges have recognized that accepting a particular case (or a series of cases) can serve to gradually alter our views. For example, in his dissent in Pittsburgh Press Co. v. Pittsburgh Commission on Human

215. John Calvin Jeffries, Jr., Rethinking Prior Restraint, 92 YALE L.J. 409, 417 (1983). 
Relations, ${ }^{216}$ Justice Stewart stated that " [i]t may be that it is the obnoxious thing in its mildest and least repulsive form; but illegitimate and unconstitutional practices get their first footing in that way ...."'217 Justice Cardozo also remarked in Allegheny College v. National Chautauqua Bank $^{218}$ that " $[\mathrm{t}] \mathrm{he}$ half truths of one generation tend at times to perpetuate themselves in the law as the whole truth of another, when constant repetition brings it about that qualifications, taken once for granted, are disregarded or forgotten."219

Bernard Williams provides a helpful example of how going through a process can serve to change our views of it. ${ }^{220} \mathrm{He}$ says that,

[I]t may well be that when a number of steps [have] been taken, the original objections to the process, or to this degree of it, now seem misplaced. The cumulative process has itself altered perceptions of that process. It is a mechanism very like that in terms of which Nelson Goodman explained that increasingly incompetent forgeries by van Meegeren were accepted as genuine Vermeers. Each new one was compared to a reference class that contained the earlier ones, and it was only when all the forgeries were bracketed, and the latest ones compared to a class of Vermeers free from van Meegerens, that it became obvious how awful they were. It is often this kind of process that critics have in mind when they claim that allowing some [practice] will lead to a slippery slope. It is a process that they see in terms of corruption or habituation, just as reformers may see it as a process of enlightenment or of inhibitions being lost. ${ }^{221}$

The Supreme Court is aware that this sort of process can take place. In United States v. 12 200-Ft. Reels of Super 8mm Film, ${ }^{222}$ the Court remarked that

The seductive plausibility of single steps in a chain of evolutionary development of a legal rule is often not perceived until a third, fourth, or fifth "logical" extension occurs. Each step, when taken, appeared a reasonable step in relation to that which preceded it,

\footnotetext{
216. 413 U.S. 376 (1973).

217. Id. at 402 (Stewart, J., dissenting) (quoting Boyd v. U.S., 116 U.S. 616, 635 (1886) (Bradley, J.)).

218. 159 N.E. 173 (N.Y. 1927).

219. Id. at 174.

220. See Williams, supra note 38, at 132; see also Jonathan Glover, What SoRT of People SHOULD THERE BE? 14 (1984) ("By easy stages, we could move to a world which none of us would choose if we could see it as a whole from the start."); id. at 17 ("A series of incremental decisions can lead us somewhere we would never have chosen to go in the first place....").

221. Williams, supra note 38 , at 132 (citations omitted).

222. 413 U.S. 123 (1973).
} 
although the aggregate or end result is one that would never have been seriously considered in the first instance. ${ }^{223}$

Justice Scalia probably had this sort of process in mind when he remarked in dissent in Stutson v. United States ${ }^{224}$ that a comparison of "the modest origins of the Court's no fault [vacate and remand] policy with today's expansive dénouement should make even the most Pollyanish reformer believe in camel's noses, wedges, and slippery slopes."225

As argued above, however, the mere fact that the cases on the slope form a continuum does not, by itself, show that we would be likely to move down the slope if we step on it. $^{226}$ In order to make their arguments as compelling as possible, proponents of SSAs should therefore provide additional reasons for thinking that a process such as the one described above will take place if a court allows the practice or policy under consideration.

\section{ii. Possible Changes in Our Norms}

One way in which a proponent of an SSA could help her case is by pointing out how allowing some practice could lead to pressures for increasing the cases in which it is used. As some commentators suggest, once we begin to make use of a practice, our views on who should make use of it often begin to change. ${ }^{227}$ As Daniel Callahan says,

In our society it is frequently the case that, when a new policy is introduced, the first stage is to say, "It's voluntary; you have a free choice." The next stage is a social consensus about what's a responsible free choice. The family planning movement is a perfect example. [In years past] ... the important thing was to educate people about family planning possibilities - then they could make a perfectly free choice. Now with the concern about population, everybody says, "Yes, you should have a free choice, but there's only one responsible free choice-a small family."228

As Callahan suggests, as certain practices become more and more available, or as their use becomes more and more common, society's views on people who do not make use of these practices may begin to shift.

223. Id. at 127 (citing Hudson County Water Co. v. McCarter, 209 U.S. 349, 355 (1908)) (“All rights tend to declare themselves absolute to their logical extreme."). In Washington v. Glucksberg, 521 U.S. 702 (1997), the Court quoted part of this passage from 12 200-Ft. Reels of Super 8mm Film, which suggests that the Court is still concemed with this process. See id. at 735.

224. 516 U.S. 193 (1996).

225. Id. at 190 (Scalia, J., dissenting).

226. See supra Part IV.B.2.a.

227. See, e.g., LAMB, supra note 30, at 117-18; Biomedical Ethics and the Shadow of Nazism, Hastings Center Rep., Aug. 1976, Special Supplement, at 16 (remarks of Daniel Callahan) [hereinafter Callahan Remarks].

228. Callahan Remarks, supra note 227, at 16. 
This possibility may be worrisome if we allow active voluntary euthanasia or physician-assisted suicide. Philippa Foot argues that

the possibility of active voluntary euthanasia might change the social scene in ways that would be very bad. As things are, people do, by and large, expect to be looked after if they are old or ill. This is one of the good things that we have, but we might lose it, and be much worse off without it. It might come to be expected that someone likely to need a lot of looking after should call for the doctor and demand his own death. ${ }^{229}$

Foot thus suggests that if we legalize active voluntary euthanasia, what begins as a voluntary choice could eventually come to be viewed as the only "responsible" choice for certain people, such as the elderly or infirm. If this happens, we may divert resources away from the care and treatment of such people, which, in turn, would reduce the options available to them. In addition, societal views on who should opt for death could influence members of the judiciary. ${ }^{230}$ This, in turn, could lead the judiciary to rule in ways that lead us down a slippery slope. In evaluating empirical SSAs, it is thus important to consider the ways in which allowing some practice may lead to changes in our views regarding who should make use of it.

\section{iii. "Landmark" Cases}

Sometimes, proponents of SSAs may also be able to support their claims by arguing that a decision to allow $A$ is likely to be viewed as a "landmark." As N. Ann Davis points out,

An event or practice that is unexceptional in itself may ... have a powerful impact on people because of how it happens to engage people's imaginations, or because of what it is taken to symbolize or signify. Whether we think of political events (like the assassination of Martin Luther King, or the revelation of Nixon's participation in the "dirty tricks" of Watergate), . . or biomedically-occasioned events (like the transplantation of a baboon heart into Baby Fae or the dispute over the parenthood of Baby $\mathrm{M}$ ), it is clear that some events have a greater capacity to engage people's imagination, to change their perspective, and to challenge their values and attitudes. Such events might be described as straws breaking a camel's back, but they are perhaps better understood as occasioning a gestalt switch, a sometimes radical reinterpretation of the familiar in light of the significance revealed by the new..$^{231}$

229. Foot, supra note 10 , at 112 (emphasis added).

230. See infra Part IV.B.2.c.

231. Nancy ('Ann') Davis, Morality and Biotechnology, 65 S. CAL. L. REv. 355, 368 (1991). 
Davis's point can be applied to certain judicial decisions. Some decisions change the course of the law; they have the effect of altering our jurisprudence by introducing some new value into it or by altering the significance we attach to some value already existent in our discourse. A groundbreaking opinion in favor of a certain departure can change the way that we view cases that are further departures from the law as it existed before that ground-breaking decision.

Numerous legal decisions can be viewed as landmarks. For example, John Calvin Jeffries, Jr. argues that Near v. Minnesota ex rel. Olson ${ }^{232}$ was such a decision because of the way that it has been used to "chart our course to future decisions" regarding prior restraints. ${ }^{233}$ The same can be said of Roe v. Wade $e^{234}$ because of its holding that "the right of personal privacy includes the abortion decision." ${ }^{.235}$ If a proponent of an SSA can plausibly claim that a case allowing $A$ is likely to be viewed as a landmark, her predictive claims will seem more compelling. ${ }^{236}$ This is especially true if we have grounds for fearing that the court would draft the opinion in such a way that it could be interpreted as allowing cases further down the slope, such as if the opinion would rely on vague terms.

In sum, when evaluating SSAs, especially those that are invoked in constitutional debates in which major values are at stake, the ways in which a particular decision may be viewed as a landmark are significant. If a decision allowing $A$ is likely to be viewed as a landmark, we may have good grounds for fearing that the judiciary will gradually allow practices further down the slope. But if the decision would instead be viewed as a minor exception to some existing rule or as a mere aberration in the course of legal thought, such worries will be less coinpelling. Speculations as to how the courts and commentators are likely to receive particular decisions are thus relevant to evaluating the empirical SSAs invoked in adjudication.

\section{Ways in Which Other Governmental Entities May Interpret Judicial Decisions}

Before concluding this Section, it should be noted that other governmental entities often interpret judicial decisions. Slippery slope dangers are also relevant then. Andrew Kimbrell inakes a compelling argument for the

232. 283 U.S. 697 (1931).

233. Jeffries, supra note 215 , at 417 . In Near, the Court reversed a decision by the Minnesota Supreme Court, which had affirmed a district court ruling that both found a publication to be "a public nuisance" and "perpetually enjoined" the publishers from "spoducing, editing, publishing, [or] circulating"" like publications. 283 U.S. at 706.

234. 410 U.S. 113 (1973).

235. Id. at 154 .

236. People who view the case as a landmark, however, might also tend to think that it reached the correct result. If so, such people may disagree with the proponent of the SSA regarding the objectionability of cases further down the slope. For more discussion of these points, see infra Part V. 
view that the Supreme Court's decision in Diamond v. Chakrabarty ${ }^{237}$ led to a slide down a slippery slope. ${ }^{238}$ This Section briefly describes this slide.

Chakrabarty addressed General Electric's (GE's) attempt to gain a patent on an oil-eating microbe. ${ }^{239}$ Interpreting section 101 of the Patent Act, ${ }^{240}$ the Supreme Court granted the patent by a 5-4 vote, suggesting that the relevant distinction was not between living and inanimate beings, but between whether or not the product could be viewed as a human-made invention. ${ }^{241}$ As Kimbrell says, "[a]ccording to Chief Justice Warren Burger's majority opinion, the oil-eating microbe was not a product of nature, it was [an] invention and therefore patentable."242

Before deciding Chakrabarty, the Supreme Court was presented with clear slippery slope warnings. The People's Business Commission, led by Ted Howard and Jeremy Rifkin, filed an amicus brief against allowing the patent, which warned both that companies' desire to increase profits could serve to eliminate public participation in the policy-making process and that a decision to allow the patent could serve as precedent for the patenting of other forms of life, including animals and perhaps eventually humans. ${ }^{243}$

The Court seemed unimpressed by this line of argument. The Justices all appeared to agree that Chakrabarty was a narrow case that did not affect "the future of scientific research."244 Chief Justice Burger even went so far as to say that the decision in no way implicated the "gruesome parade of horribles" cited in the petitioner's and the amicus briefs. ${ }^{245}$

In retrospect, however, the slippery slope fears raised in Chakrabarty seem well-founded. Kimbrell argues that "the patenting of microbes led to the patenting of plants, and then animals, and finally human genes and

237. 447 U.S. 303 (1980).

238. See KIMBRELL, supra note 195, at 192-212.

239. See id. at 192-94. It should be noted that by the time the Supreme Court decided Chakrabarty, GE no longer had any intention of marketing the microbe. Kimbrell notes that "[alpparently, while the microbe would eat oil in the lab, years of tests had proven it was too fragile to function in the open seas, where it was most needed." $I d$, at 193 . Kimbrell goes on to say that

GE's motives in continuing its patent quest, despite the fact that it no longer had a viable product, were simple if not pure. It was using the ... patent claim ... as an altruistic-secming test case to establish the ground rules for the patenting of life. If the GE patent succeeded, the patent profit floodgates would be opened. GE and other corporations could then maximize their profits in the coming multibillion-dollar biotechnology industry.

Id. at 193-94. This point illustrates one of the ways in which economic considerations may lead a corporation to attempt to "push" us down a slippery slope.

240. 35 U.S.C. $\$ 101$ (1994).

241. See Chakrabarty, 447 U.S. at 309-10; see also KIMBRELL, supra note 195, at 195 (discussing the Court's holding).

242. KIMBRELL, supra note 195, at 195.

243. See id.

244. Chakrabarty, 447 U.S. at 318 (Brennan, J., dissenting); see also KIMBRELL, supra note 195, at 195 (discussing this apparent agreement).

245. Chakrabarty, 447 U.S. at 316. 
tissues. ${ }^{.246}$ On April 12, 1988, the Patent and Trademark Office (PTO) issued the first patent on a living animal, which was a transgenic mouse that contained a number of genes found in other species, such as humans and chickens. ${ }^{247}$ On December 29, 1992, the PTO announced that it was granting patents for three more genetically engineered mice. ${ }^{248}$ By 1993, there were over 190 animals "figuratively standing in line" to be patented. ${ }^{249}$

Kimbrell argues that these subsequent patents are a direct result of Chakrabarty. ${ }^{250}$ He notes that in 1985, the PTO ruled that Chakrabarty "'could be extended to include the patenting of genetically engineered plants, seeds, and plant tissues." ${ }^{251}$ On April 7 of the same year, the PTO issued a ruling that specifically extended Chakrabarty to include all "'multicellular living organisms, including animals." "'s52 And on October 29, 1991, the PTO granted a patent on human bone marrow stem cells that had not been engineered in any way. ${ }^{253}$ Scientists involved in the Human Genome Project are currently trying to map the human genome, ${ }^{254}$ and patenting human DNA sequences has become "a booming industry."25s

According to Kinbrell, occurrences such as these "provide an important perspective from which to survey the influence of the Supreme Court's ill-advised decision in Chakrabarty." 256 He says that

Most of the "gruesome parade of horribles" predicted by those opposing the 1980 patent decision[] have become, with dizzying rapidity, realities. The distance traveled since the Chakrabarty decision in furthering the patenting of life can be highlighted by considering whether the [C]ourt, in 1980, would have still ruled that life-forms were patentable had the organism in question not been a lowly, ineffective, oil-eating bacteria, but rather a human embryo, or a genetically engineered chimpanzee, or the entire set of over 100,000 human genes. The answer is clearly no. The Supreme Court would never have ruled for the patenting of these other living organisms or human subparts. Any such decision would have led to an immediate public uproar. Yet, through the

246. KIMBRELL, supra note 195, at 197; see also ROBERT P. MERGES ET AL., INTELLECTUAL Property IN THE New Technological AGE 150 (1997) (citing subsequent decisions that have "uniformly extended" the rule of Chakrabarty "to allow the patenting of 'new' plants and animals, including mammals").

247. See KIMBRELL, supra note 195, at 197.

248. See id. at 198.

249. Id.

250. See id. at 199.

251. Id. (quoting Animals-Patentability (US Patent and Trademark Office, April 7, 1987)).

252. Id.

253. See id. at 210-11.

254. See id. at 139-40.

255. MERGES ET AL., supra note 246, at 150 (citation omitted).

256. KIMBRELL, supra note 195, at 211. 
slippery slope descent [described above] ... just such an expansion of patenting has occurred. ${ }^{257}$

Kimbrell's analysis illustrates several important points. First, it shows that worries about slides down empirically slippery slopes can be valid. Second, it highlights some of the ways in which powerful entities such as corporations may have economic incentives to see us slide down a slippery slope, and how they may accordingly exert pressures on the courts, society, or governmental agencies to help ensure that this happens. Third, Kimbrell's remarks illustrate that the judiciary is not an isolated entity; its decisions can be interpreted by other entities with rule-making powers. In some cases, this may lead to slippage. Given this last point, it is important for judges to contemplate how their decisions will be interpreted by entities outside the judiciary.

\section{Evaluating Empirical SSAs}

While empirical SSAs can be valid arguments, it can be exceptionally difficult to evaluate their strength. The future is inherently uncertain; we may not always be able to give accurate assessments of where allowing a practice could lead. But we can still make general remarks regarding how to evaluate empirical SSAs. This Section provides some such general guidelines.

\section{a. The Likelihood of Sliding down a Slope and the Objectionability of Its Steps}

Nils Holtug argues that the strength of an empirical SSA will generally "depend on both how probable the causal connection (between $A$ and B) is, and on how much we want to avoid B... . [T] he more probable the causal connection is, and the more we want to avoid $B$, the stronger the argument."258 These two points suggest that the more objectionable $B$ is, the less probable need be the connection between $A$ and $B$ in order for the relevant SSA to give us sufficient grounds for resisting $A$. As Holtug notes, "if $B$ is a nuclear catastrophe it would need not to be as probable as if $B$ was one person becoming ill, to give us sufficient reason to refrain from allowing A." 259

But even if we find it highly implausible that allowing $A$ would lead to an allowance of $B$, we should still consider the likelihood of allowing $A$ leading to an allowance of other steps on the slope. In some cases, we may doubt that allowing $A$ would lead to an allowance of $B$, but still find it plausible that allowing $A$ would lead to a toleration of, say, $p$, which is itself objectionable (although perhaps not as objectionable as $B$ ). For

257. Id. at 211-12.

258. Holtug, supra note 8, at 404 .

259. Id. 
example, someone could be extremely skeptical that allowing active voluntary euthanasia would lead us to tolerate involuntary euthanasia. She may still think, however, that allowing active voluntary euthanasia would lead us to allow certain objectionable forms of nonvoluntary euthanasia, such as perhaps the killing of "defective" infants or people in persistent vegetative states who do not have living wills. In some cases, allowing $A$ may lead to an objectionable state of affairs, even if it does not lead all the way to the bottom of the slope. In evaluating empirical SSAs, we must therefore attempt to determine the likelihood of allowing $A$ leading to an allowance of other steps along the slope, as well as the levels of objectionability of these steps. The more probable it is that allowing $A$ will lead to some objectionable state of affairs, and the more objectionable we take this state of affairs to be, the stronger the reasons are for resisting $A$.

\section{b. The Grounds in Favor of Allowing A}

Holtug also points out, however, that the strength of an empirical SSA is inversely proportional to the grounds in favor of allowing $A .^{260}$ As he says, "the more desirable allowing $A$ is, the weaker the argument." ${ }^{\text {"261 }}$ In some cases, we have excellent reasons for allowing $A$. For example, allowing active voluntary euthanasia or physician-assisted suicide would arguably reduce the amount of pain and suffering in the world ${ }^{262}$ and enable us to accord greater respect to individuals' autonomy. ${ }^{263}$ Along these lines, John D. Arras argues that the right to die is traceable to the legal right to privacy and the moral right to self-determination. ${ }^{264} \mathrm{He}$ thus suggests that the alternatives in the debate concerning the legalization of active voluntary euthanasia are rather clear: "If we allow the practice of euthanasia, we risk an uncertain future harm of great magnitude; but if we maintain the status quo, we violate the rights of definite individuals here and now, an evil of lesser proportions, but of much greater certainty and concreteness."265 In light of these points, Arras thinks that a patient's right to die trumps the relatively speculative slippery slope fears. ${ }^{266}$

Proponents of SSAs, however, often ignore the negative consequences of refusing to allow A. Jeffrey P. Whitman argues that SSAs are frequently invoked when we are confronted with a "tragic choice": 267

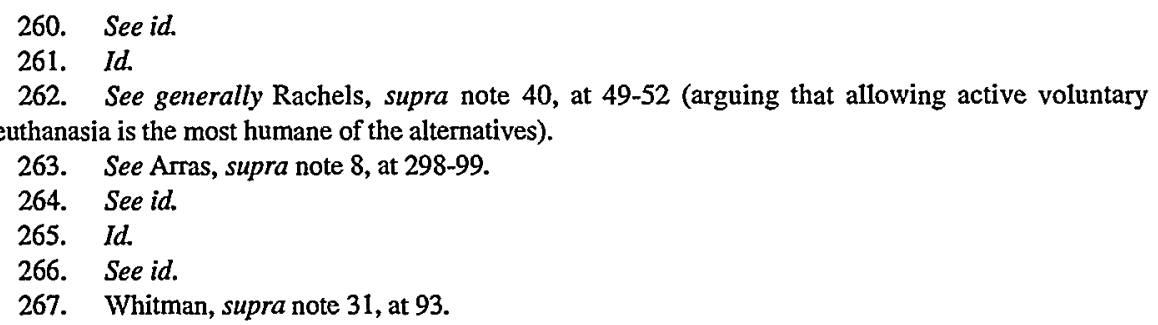


All too often the slippery slope argument represents a reluctance or failure to see the moral, social, and economic cost of the status quo. It is a failure to recognize (either wittingly or unwittingly) that resisting change ... is itself a tragic choice. . . . Barring euthanasia means accepting the continued suffering and pain of terminally ill persons and all the costs (social, emotional, and economic) this entails. In the final analysis, there really is no escaping the tragic choice. The slippery slope argument is pernicious in the extreme when it leads us to believe otherwise. ${ }^{268}$

When we are evaluating SSAs, we must therefore take into account the problems associated with refusing to allow $A$. The stronger the grounds in favor of allowing $A$, the bigger is the burden on the relevant SSA to show that we should not.

\section{c. Concluding Remarks}

The strength of particular empirical SSAs depends on a few considerations. First, the strength of such arguments is proportional both to the plausibility of the claim that allowing $A$ will lead to various steps on the slope and to the level of objectionability of these various steps. Second, the strength of empirical SSAs is inversely proportional to the weightiness of the reasons in favor of allowing $A$.

These remarks also shed light on ways to undermine empirical SSAs. First, one could argue that it is unlikely that allowing $A$ will lead to a slide down a slippery slope. ${ }^{269}$ Second, one could argue that the steps on the slope are not really objectionable. ${ }^{270}$ Third, one could argue that even if the SSA has some predictive merit and the steps on the slope are objectionable, the relevant slippery slope fears are outweighed by other considerations, such as the grounds in favor of allowing $A .{ }^{271}$ Finally, one could criticize an empirical SSA through some combination of these three arguments.

Given the remarks made in this Part, a strong einpirical SSA would make use of nuinerous points. For example, it may show us how there is a continuum of closely related cases between $A$ and $B$. It might also describe

268. Id.

269. See, e.g., Arras, supra note 8, at 298 (suggesting that society's concern for individual rights and autonomy gives us grounds for thinking that allowing active voluntary euthanasia would not lead to a slide to an objectionable state of affairs); Rachels, supra note 40, at 70-71 (citing historical, anthropological, and sociological evidence for thinking that allowing active voluntary cuthanasia would not lead to a toleration of objectionable forms of killing).

270. See, e.g, Resnik, supra note 8, at 36-39 (arguing that possible bottoms of the slope necd not be objectionable in the case of human gene therapy). It is possible, however, that this second strategy will backfire: One's audience may think that if people are already arguing that the steps on the slope are not objectionable, allowing $A$ could lead to immense pressures to move down the slope. Thus, rather than convincing one's audience that we should allow $A$, this line of argument may make them even more opposed to doing so.

271. See infra Part IV.B.4.b. 
the ways in which a ruling allowing $A$ would necessarily make use of vague terms. In addition, it might point out how the climate both of judicial and of public opinion would be highly conducive to a slide down the relevant slippery slope. Furthermore, it might provide us with grounds for believing that a decision allowing $A$ would be viewed as a landmark that would change the way we view the law in a given area. Finally, the proponent of the SSA could argue that the grounds in favor of allowing $A$ are not very strong. Conversely, an extremely weak empirical SSA would be one invoked in a context in which none of these points held true.

Unfortunately, however, evaluating empirical SSAs generally will not be so easy. Given the complexities of many legal issues, the factors discussed above may all be present or absent in varying degrees. Some of these factors may even have inverse relationships with one another. For example, if there is a strong climate of opinion in favor of allowing cases further down the slope and a decision allowing $A$ is likely to be viewed as a landmark, the grounds in favor of allowing $A$ may also be rather strong. Thus, there may be very few empirical SSAs that are knock-down arguments, and few that are worthy of little consideration. Because of all the factors that can influence the strength of particular empirical SSAs, we can make no sweeping generalizations regarding the strength of such arguments as a class.

This result may be unwelcome to some. One might wish to be told either that all empirical SSAs are good arguments or that all such arguments are bad ones. This would make the task of evaluating empirical SSAs much easier. It would also be desirable if someone could provide a simple algorithm that we could use to definitively evaluate the strength of every possible empirical SSA. But given the numerous considerations relevant to evaluating such arguments, it does not appear that this can be done.

As this Section suggests, evaluating empirical SSAs will often entail making a series of complex inquiries. Close attention must be paid not only to the practice or policy under consideration, but also to the social context in which it would be introduced. One inust also balance the relevant slippery slope considerations against the grounds in favor of allowing $A$. Even after making such assessnents, reasonable people may disagree about the strength of particular empirical SSAs.

\section{Roles that SSAs Can Play in Judicial Decision Making}

While it can be extremely difficult to evaluate particular SSAs, such arguments can still play important roles in judicial decision making. As Schauer states, an SSA "emerges as an appeal that forces decisionmakers to focus on the future iniplications of what they do today."272 Although

272. Schauer, supra note 1 , at 382. 
such appeals are also made outside the legal context, "it may be that legal decisionmaking concentrates on the future more than does decisionmaking in other arenas."273 Schauer thus argues that law,

perhaps more emphatically than other decisionmaking mechanisms, calls upon today's decisionmakers to consider the behavior of others who tomorrow will have to apply or interpret today's decisions. The prevalence of slippery slope arguments in law may reflect a societal understanding that proceeding through law rather than in some other fashion involves being bound in some important way to the past, and responsible in some equally important way to the future. ${ }^{274}$

Because SSAs draw attention to the possible future implications of today's decisions, such arguments play valuable roles in judicial reasoning. This Section discusses some of the important roles that SSAs can play.

\section{SSAs Can Motivate a Court to Resist Some Practice or Policy}

In some cases, SSAs may give judges compelling reasons for refusing to allow some practice. A judge may think that because of slippery slope considerations, allowing that practice is likely to have worse consequences than would a refusal to allow it. A judge may also be unsure of the strength of the claims of the relevant SSA but think that only nominal reasons exist in favor of allowing $A$. Because of the relevant slippery slope considerations and the relatively weak reasons for allowing $A$, a judge may think that the risks of allowing it are simply too great.

\section{SSAs Can Influence the Way that Judges Draft Their Opinions}

SSAs can also play valuable roles in judicial reasoning, even in cases in which a court does not think that such arguments provide it with sufficient grounds for resisting the relevant practice altogether. Some SSAs may at least give judges grounds for concern; this concern may motivate them to draft their opinions in ways that lessen the probability of a slide to some objectionable state of affairs.

Consider those empirical SSAs that oppose allowing active voluntary euthanasia or physician-assisted suicide. A judge may disagree with some of the predictions and assumptions on which these arguments rely. For example, even if allowing either of these practices would be likely to lead the courts to allow some other practices, a judge may believe that none of these other practices are clearly objectionable. She might think, for instance, that the likelihood of the courts allowing objectionable practices would be reduced by people's ability to distinguish between different forms of killing. This, combined with the emphasis that our society places

273. Id.

274. Id. at 383 . 
upon individual rights and autonomy, may provide excellent reasons for finding it extremely unlikely that allowing either of these practices would lead to a slide to a highly objectionable state of affairs. And even if a judge is not sure of the likelihood of such a slide, she may believe that people have a right to die that trumps speculative slippery slope fears. Given these considerations, a judge may think that the relevant SSAs do not provide sufficient grounds for refusing to give patients greater control over life and death decisions.

But the relevant SSAs may still provide judges with some grounds for concern. For example, judges may be concerned about: (1) critical indeterminacies in key terms used in the relevant statute or possible judicial decision recognizing a right to die; (2) the slope of closely related cases between paradigm instances of active voluntary euthanasia and physicianassisted suicide and other, more problematical, cases; and (3) the relative prevalence of economic modes of thinking among the judiciary, which could help lead judges to become increasingly more tolerant of physicians who help end the lives of people whom it is expensive to keep alive. By providing judges with some grounds for concern, the relevant SSAs can motivate judges to clarify what they mean in using vague terms, as well as to specify the cases in which they think that euthanasia or physicianassisted suicide would not be justified. By making judges aware of the possible future pitfalls of the decisions they make today, SSAs can put courts in a better position to navigate around these pitfalls. Thus, SSAs can play valuable roles in judicial decision making, even if judges do not accept all of the claims of the SSAs.

\section{Concluding Remarks}

As Schauer notes, however, it will often be impossible, impractical, or even undesirable for judges to specify all of the cases they mean to exclude. ${ }^{275}$ And even if judges could do so, they would generally do so in dicta. Judges deciding future cases could ignore such exclusions and decide that the reasons for allowing $A$ or $m$ also apply to allowing cases further down the slope. Thus, even if a judge strives to write an opinion that will best avoid a slide, there is still no guarantee that slippage will not result.

Nonetheless, it is important for judges to consider and address the possible slippery slope implications of their decisions. In some cases, the relevant SSAs may provide courts with good grounds for resisting some practice or policy. In other cases, such arguments nay at least motivate judges to draft their opinions in ways that could lessen the relevant slippery

275. See id. at 371-73. 
slope dangers. By failing to address the claims of certain SSAs, judges may neglect their responsibility to the future.

\section{$\mathrm{V}$}

\section{The Value of Reflecting on the Bottom of the Slope}

Part IV argued that evaluating empirical SSAs can be a difficult matter. This Part seeks to introduce a further complication into our assessments of SSAs. It argues that even if we think that the literal claims of a particular SSA are rather weak, reflecting on the practices or policies allegedly toward the bottom of the slope still can shed light on troublesome aspects of the case at the top. Such reflections can give us grounds for resisting $A$, even if we are skeptical of the literal claims of the relevant SSA.

This Part also argues that engaging in such reflections may best enable us to address the deeper concerns that lie behind people's uses of SSAs. Some SSAs can be viewed, at least in part, as expressions of disapprobation toward allowing $A$. Allowing $A$ will often represent the corruption of some value that is important to the proponent of the SSA. This corruption will frequently be accentuated or magnified in the case of $B$. Considering $B$ thus can put us in a better position to understand why the proponent of the SSA is troubled by the thought of allowing $A$. This, in turn, may enable us to do more justice to the deeper concerns that lie behind her invocation of the argument.

In light of these points, this Comment argues that there are good reasons for rethinking some of the roles that SSAs can play in legal reasoning. While the predictions of empirical SSAs can give us grounds for resisting various practices or policies, this Comment argues that even if we think that such predictions fail to do this, considering the case at the bottom of the slope can still shed light on problems associated with the case at the top. Such considerations can be used to raise profound questions about what allowing $A$ would mean about the society that allows it. In some cases, these considerations may give us grounds for resisting $A$, even if we think that the SSA fails as a rational argument.

\section{A. SSAs and Ideologies}

Before getting to the main arguments of this Part, it will be helpful to consider some of the factors that can motivate people's uses of SSAs. Doing so will help clarify some of the concerns that underlie people's uses of the arguments. This, in turn, will lead to a better understanding of the sort of threat that allowing $A$ may represent to the proponents of SSAs. After discussing one possible factor that may motivate the use of SSAs, this Section follows David J. Mayo in arguing that SSAs tend to be made in response to perceived threats to people's ideologies. 


\section{Pessimism and Optimism}

One factor that may motivate the use of a particular SSA is a belief that allowing $A$ would be likely to lead to a slide down a slippery slope. This explanation, however, provides us with little sense of why someone may think this is so.

Wibren van der Berg attempts to provide such an explanation by arguing that SSAs tend to be motivated by a pessimistic outlook. ${ }^{276} \mathrm{He}$ also argues that people's differing views on the strength of particular SSAs are frequently reflections of their differing levels of pessimism and optimism: Those who invoke such arguments tend to be pessimists, while those who criticize such arguments tend to be more optimistic. ${ }^{277}$

But it is an oversimplification to hold that appeals to SSAs are motivated by a pessimistic outlook alone. One might think, for example, that empirical SSAs against allowing human gene therapy are rather compelling, but that those that oppose allowing physician-assisted suicide are much more weak. If taken by themselves, van der Burg's remarks offer little explanation of how this can be the case. Is a person simply being pessimistic in one case but optimistic in the other? Even if she is, tracing her views to differing levels of pessimism and optimism alone offers little explanation of why this is so. Indeed, one may be able to offer evidence for thinking that the claims of one empirical SSA are more compelling than those of another. But then her views are traceable to more than just pessimism and optimism alone.

\section{Ideological Differences}

Mayo provides a more satisfactory explanation, both of the motivational factors behind people's uses of SSAs and of why such arguments will be unconvincing to others. He argues that people tend to invoke SSAs in response to perceived threats to their ideology; people with differing ideologies will thus tend to reject the claims of such arguments. ${ }^{278}$

"A full-blown ideology articulates both a perception of The Good, or how things ought to be, and interpretative principles for viewing and explaining the current social or political reality. ${ }^{\text {'279 }}$ Implicit in an ideology is a standard for measuring progress toward-or deterioration from - how the world or society supposedly should be. ${ }^{280}$ 'Such progress or deterioration can take many forms: "legislation, court rulings, election or appointment (or even just public recognition) of ideological spokespersons, policy rulings, or mstitutional endorsements of every sort and at every level, and

276. See van der Burg, supra note 29, at 64-65.

277. See id.

278. See Mayo, supra note 18 , at $94-96$.

279. Id. at 93.

280. See id. 
perhaps most important of all, public acceptance or rejection of [that] ideology."281

In pluralistic societies such as ours, competing ideologies can each have many adherents. ${ }^{282}$ For example, some members of our society can be called "religious fundamentalists," while others subscribe to a classical liberal view. The former may believe that society is justified in prohibiting actions that (they believe) are contrary to God's will, even if such actions cannot be shown to harm anyone other than the person who performs them. The latter frequently subscribe to John Stuart Mill's harm principle and hold that the only justifiable reason for interfering with an adult's liberty is to prevent harm to others. ${ }^{283}$

Some practices or policies will be in direct violation of (or conformity with) a particular ideology's vision of how the world should be. When this happens, adherents of that ideology often give straightforward arguments against (or in favor of) that policy. For example, "the fundamentalist ideology yields straightforward arguments against state recognition of homosexual marriage, whereas the classic liberal ideology yields straightforward arguments in favor of" it. ${ }^{284}$

Frequently, however, the conflict between a proposed practice and a particular ideology's vision of The Good is not so obvious. If the proposed practice offers obvious benefits, it "may experience considerable popularity." 285 When this happens, the ideologue "will try to sound the warning of long-term consequences, by pointing to what he perceives as the corruption which this [practice] represents, and the further corruption of The Good which it invites." 286 Mayo thus thinks that invoking an SSA is a natural response for someone who thinks that her ideology is being (at least subtly) threatened by a particular practice or policy. ${ }^{287}$

One's ideology may also color one's views, both on what a practice represents and on the further consequences that allowing it invites. ${ }^{288}$ For example, those who think that

all non-marital sex is contrary to God's will and out of step with the "natural order" of things[] are more inclined to see human misery as its inevitable outcome. This naturally colors their

\footnotetext{
281. Id.

282. See id.

283. See John Stuart Mill, ON Liberty 8 (R.B. McCallum ed., Basil Blackwell 1946) (1859):

[T] he sole end for which mankind are warranted, individually or collectively, in interfering with the liberty of action of any of their number, is self-protection.... [T] he only purpose for which power can be rightfully exercised over any member of a civilised community, against his will, is to prevent harm to others.

284. Mayo, supra note 18, at 93 .

285. Id. at 94 .

286. Id.

287. See id.

288. See id.
} 
interpretation of data on various sex-related issues, e.g., whether AIDS education which preaches abstinence is optimally effective for slowing the spread of $\mathrm{HIV}{ }^{289}$

In contrast, gay activists tend to have differing views, both about the value of non-marital (or non-procreative) sex, and about what society should and should not tolerate. Mayo says that "[d]isparity about values here not only feeds on (and is fed by) different . . . counterfactual commitments, but also by competing theoretical commitments in theology, and psychology (to name but two).",290

According to Mayo, then, people's differing views on the strength of a particular SSA are frequently reflections of ideological differences between them. ${ }^{291}$ He says that SSAs are often

surface embodiments of ideological conflicts: to those who advance them they represent statements of fundamental concerns about perceived threats to the vision of the good which they embrace, while those at whom they are directed often do not share that vision, and may even embrace a competing ideology according to which the "threatened corruption" actually represents desirable progress. ${ }^{292}$

Mayo's remarks hold true for many of the SSAs invoked in legal debates. Consider those SSAs against allowing either active voluntary euthanasia or physician-assisted suicide. People who make such arguments tend to be disturbed by the corruption of our views that they believe such practices would represent, and by the further corruption that allowing such practices may invite. Proponents of the relevant SSAs may think that human life is of special, or even paramount, importance. As such, they will frequently be bothered by the thought of cost-benefit or quality-of-life considerations playing larger roles in life and death decisions. Since people's decisions to die would generally be made on quality-of-life grounds, proponents of the relevant SSAs may think that allowing active voluntary euthanasia or physician-assisted suicide would lead society in the wrong direction. Their uses of SSAs are thus motivated, at least in part, by perceived threats to their ideologies or value systems.

Critics of the relevant SSAs, however, generally have much different views. They may emphasize the importance of individual autonomy instead of the infinite value of human life. They will also tend to favor making some life and death decisions on quality-of-life grounds: They may argue that it is our biographical life rather than our mere biological life that has value, and that being alive in a biological sense is important

289. Id. at 95 .

290. Id.

291. See id. at $95-96$.

292. Id. at 96. 
only because it helps enable us to carry out our plans, wishes, and endeavors. ${ }^{293}$ Insofar as we now have the technology to continue our biological lives past the point where our biographical lives are no longer worth living, such people may argue that the way to best respect the aspects of human life that are valuable is to recognize the right to die. ${ }^{294}$ At least in part because of their differing views on the valuable aspects of human life, proponents and critics of an SSA will have differing views on the argument's strength.

Differing views and values lead to another difficulty in evaluating empirical SSAs. Such arguments may be highly convincing to people with one set of views and values and extremely implausible to those with another. It may therefore seem that there is no neutral, value-free ground on which we can stand to evaluate the strength of the arguments: Our evaluations will necessarily be colored by subjective, value-based considerations.

But the problems associated with the lack of a neutral vantage point are not unique to SSAs. Indeed, the same point could be made about nearly every argument invoked in debates concerning law and social policy. Such problems also may not be insurmountable. Even people with differing ideologies may share some of the same values; appeals to those shared values may be able to change some people's minds. This Part argues that reflecting on the cases toward the bottom of the slope will often give us a better sense of the ways in which allowing $A$ is a threat to certain shared values. In some cases, such reflections may provide us with grounds for resisting the practice or policy under consideration, even if we are skeptical of the literal claims of the relevant SSAs.

\section{B. Reflecting on the Bottom of the Slope}

This Section argues that reflecting on cases further down the slope will often lead to a better understanding of the problems associated with the practice under consideration. ${ }^{295}$ We frequently have strong reasons in favor of allowing $A$; such reasons can blind us to some of its potential drawbacks. By thinking about the prospect of allowing $B$, we can consider a case in which some of the problems of allowing $A$ are accentuated or exaggerated, and thus more fully brought to light. Such considerations can give us grounds for resisting $A$, even if we can draw a rationally defensible line along the slope and think that it is extremely unlikely that allowing $A$ would lead to a highly objectionable state of affairs. Thus, even if we are

293. See, e.g., James Rachels, Created From Animals 198-205 (1990).

294. Cf. RONALD DWORKIN, LIFE's Dominion 217 (1993) ("Making someone die in a way that others approve, but he believes a horrifying contradiction of his life, is a devastating, odious form of tyranny.")

295. My thinking on this point has been influenced by the writings of, and conversations with, $N$. Ann Davis. 
skeptical of the literal claims of an SSA, considering the bottom of the slope can still provide grounds for resisting the case at the top.

\section{Preliminary Remarks}

N. Ann Davis notes that reflecting on dystopian scenarios will sometimes enable us to gam a better understanding of the problems implicit in our practices. ${ }^{296}$ She says that

because we are engaged with our own practices, we are sometimes unable to see that the assumptions that underlie them are only assumptions not obvious truisms. We can thus best-and sometimes only-see some of the problems implicit in our practices by standing back from them, and imagining scenarios that accentuate some of their features. ${ }^{297}$

Davis's point can also be applied to practices that we are contemplating allowing. SSAs can be used to generate hypothetical states of affairs to which our allowing some practice could eventually lead. Thinking about these possible future states of affairs will sometimes illummate problems implicit in the practice that is allegedly at the top of the slope.

This Section considers how reflecting on cases further down the slope can help shed light on troublesome aspects associated with certain restrictions on free speech. It then discusses how similar points can be made about arguments pertaiming to human gene therapy and recognizing a right to die. It concludes by arguing that even though reflections on the bottom of the slope will not always be conclusive, it can still be important for us to engage $\mathrm{m}$ them.

\section{Free Speech}

a. The Skokie ${ }^{298}$ Case

One context in which this view of SSAs is relevant is debates concerning the freedom of expression of the Nazis. In 1977, the National Socialist Party (the Nazis) sought to march in Skokie, Illinois. ${ }^{299}$ At the tinie of the planned march, about sixty percent of the citizens of Skokie

296. See Davis, supra note 231 , at 362 n.15.

297. Id.; see also Glover, supra note 220, at 132 (discussing how considerations of situations that threaten our values can be used to highlight these values). Davis illustrates this point by constructing a fable that sheds light on some of the problems posed by various uses of biotechnologies. See Davis, supra note 231, at 361-63.

298. National Socialist Party of Am. v. Village of Skokie, 432 U.S. 43 (1977) (per curiam); Collin v. Smith, 578 F.2d 1197 (7th Cir. 1978) (striking down a Skokie ordinance that prohibited the dissemination of any material that promoted or incited racial or religious hatred); Skokie v. National Socialist Party, 373 N.E.2d 21 (Ill. 1978).

299. See FEINBERG, supra note 17, at 86. For helpful discussions of the Skokie controversy, see Donald AleXander Downs, Nazis in Skokie (1985); Feinberg, supra note 17, at 86-93; and ARYEH NEIER, DEFENDING MY ENEMY (1979). 
were Jewish; many of these people were also Holocaust survivors. ${ }^{300}$ Allowing the march would have been likely to have had negative consequences: It could have led many people who lived in Skokie to suffer emotional trauma ${ }^{301}$ and might even have led to violence in the streets. ${ }^{302}$ The march could also have negatively affected the views and values of some impressionable young people because of the publicity it was likely to receive. Given these possible negative consequences, as well as the abhorrence of Nazi views and values, preventing the march seems highly justifiable.

Such considerations, however, can blind to us to the fact that placing restrictions on the Nazis' freedom of expression is what was at issue. These considerations can also lead us to neglect the importance that we typically place on freedom of speech. SSAs can help us generate hypothetical states of affairs to which such restrictions could lead. For example, restricting the Nazis' freedom of expression could lead to other such restrictions, and then others, and then still others, until we finally come to censor, for instance, people with unpopular religious views. Independently of what we think about the likelihood of this actually happening, considering this hypothetical scenario illustrates troublesome aspects of restricting the Nazis.

In order to see why this is so, it is helpful to consider what would be wrong with censoring people with unpopular religious views. We may be bothered by the thought of such censorship because we think that the relevant policies would stem from the majority's or our political leaders' disagreement with those with these unpopular religious views. We also may be struck by the ways in which such censorship would violate what many people regard as the right to freedom of expression. The thought of a society that tells people what they can and cannot say is troublesome because such censorship may influence what people will and will not think. This seems clearly intolerable in the area of religious thought and expression. Such instances of censorship are surely abhorrent to our democratic views and values.

In imagining a society that has slid down the slope, we can identify tendencies present in our own society. Many people desire to "silence" others with whom they disagree; we may worry that this tendency will become magnified if the relevant restrictions are allowed. As Lee C. Bollinger argues, a desire to protect the Nazis' speech can be viewed as "a symbolic act indicating an awareness of the risks and dangers of

300. See FeINBERG, supra note 17 , at 86 .

301. See, e.g., Downs, supra note 299 , at 85-90.

302. See id. at 56-57, 92-93; NE1ER, supra note 299 , at 59. 
intolerance ...."303 Reflecting on possible bottoms of the slope can help illustrate these risks, as well as the desirability of tolerance.

Thinking about cases further down the slope also sheds light on how imposing restrictions on the Nazis conflicts with our views on the value of freedom of thought and expression. Like the society that silences people with unpopular religious views, allowing such restrictions on the Nazis would make us a society that silences people with whom the majority, the judiciary, or our political leaders disagree. While such silencing may be more dramatic in the cases toward the bottom of the slope, thinking about such cases can help us see that such silencing would also be involved in allowing the restriction at the top. Reflecting on cases in which such problematical features of a practice are accentuated or exaggerated can put us im a better position to see these features in the practice under consideration.

Considering cases toward the bottom of the slope also allows us to see how allowing such restrictions on the Nazis would move us closer to being the sort of society we claim to deplore and further away from being the sort of society we profess to be: By placing the relevant restrictions on the Nazis, we would take a step toward being the sort of society that censors people with unpopular religious views. Looking at the bottom of the slope can thus motivate us to ask important questions about what allowing the case at the top of the slope would say about our commitment to certain values, and about what allowing such restrictions would mean about us as a society.

Empirical SSAs against allowing restrictions on the freedom of the expression of the Nazis can thus be used to illustrate at least two important points. First, such SSAs can be used to show how allowing such restrictions could slowly and inexorably lead to other restrictions, and then others, and then still others, until we finally come to allow restrictions that are clearly objectionable. Second, such SSAs can be used to show that allowing the relevant restrictions would have a profound meaning as a practice: Allowing such restrictions would move us further away from being the sort of society that we claim to be and closer to being the sort of society we profess to deplore. Tolerating such restrictions may therefore have a profound symbolic value. In reflecting on a society at the bottom of the slope, we can see the threat to our values that prohibiting the Nazis from marching would represent. This latter consideration provides us with grounds for resisting such a prohibition, independently of what we think about the predictive merit of the relevant SSAs.

303. Lee C. Bollinger, The Skokie Legacy: Reflections on an 'Easy Case' and Free Speech Theory, 80 MiCH. L. REv. 617, 631 (1982) (book review) (reviewing NEIER, supra note 299). 


\section{b. Flag Burning}

The view of SSAs sketched in this Part is also relevant to debates concerning the prohibition of flag burning. As discussed in Part $1 \mathrm{~V}$, in Texas v. Johnson ${ }^{304}$ the United States Supreme Court used an SSA as a partial justification for its decision to affirm the Texas Court of Criminal Appeals' reversal of Gregory Lee Johnson's conviction for burning an American flag at a political demonstration. ${ }^{305}$ Regardless of what we think about the merits of the literal claims of this SSA and similar SSAs, reflecting on possible slippery slopes can illuminate problematical aspects of allowing a prohibition on flag burning.

Douglas Walton discusses a Doonesbury comic strip in which an SSA was invoked against such a prohibition. ${ }^{306}$ In this comic strip, Zonker asks Mike what he thinks about a proposed constitutional amendment that would prohibit flag burning: $:^{307}$

Mike: I'm for it. Aren't you?

Zonker: Sure! How could anyone be for flag-burning?

Mike: Beats me. Of course, 'physical desecration' is a tricky business . . . . For instance, will it be illegal to burn a paper flag? Or to tear up a photo of a flag? How about cutting a cake decorated with a flag? And what about flag clothing? Are you a patriot if you wear a flag T-shirt, but a felon if you wear flag pants? And what does that make Uncle Sam? And what about art-who decides whether a flag painting is a desecration or an homage? Also, what about other national symbols, like the eagle or the Statue of Liberty? Or state flags? Or the confederate flag? All sacred to somebody-should they be protected? Also, since burning is the only sanctioned way of disposing of a worn-out flag, aren't we really outlawing an idea instead of an act? And, if so, what other ideas do we outlaw? ${ }^{308}$

As Walton notes, this SSA highlights important points about problems associated with prohibiting flag burning:

the way of phrasing the final step in the sequence as 'outlawing an idea instead of an act' is a very nice way of linking the sequence of argumentation to abstract considerations like freedom of speech, clearly an important legal consideration but one the public seemed to find hard to take very seriously as a real danger, judging from other commentaries on the issue. ${ }^{309}$

304. 491 U.S. 397 (1989).

305. See supra notes 118-27 and accompanying text.

306. See WALTON, supra note 4, at 275-76.

307. See id. at 275 .

308. Id. (quoting G.B. Trudeau, Doonesbury, Winnipeg Free Press, Aug. 12, 1989).

309. Id. at 276 . 
Considering possible bottoms of the slope illuminates problems implicit in allowing the relevant prohibition. If burning is the only sanctioned way of disposing of a worn-out flag, a prohibition on flag burning really would outlaw the expression of ideas, rather than a mere act. This, however, is in sharp conflict with values underlying the First Amendment that this country holds dear: Perhaps the major reason why we think that we should have freedom of speech is so that we can express our ideas, especially our political ones. Thinking about a possible bottom of the slope can thus help illuminate problematical features of a prohibition on flag burning.

By taking the reader through this series of intervening and gradual steps, the Doonesbury SSA may also lead the reader to consider the possible absurdities associated with the relevant prohibition. Such absurdities may have been lost on the public in the wave of patriotic sentiment that followed the Johnson case..$^{310}$ By taking us through this series of steps, we can see the similarities that each step has with the prohibition under consideration. Considering this SSA thus enables us to take a step back from that prohibition and consider cases in which its disturbing features are magnified. We are then able to see such features more clearly because our attention has been drawn away from the reasons in favor of prohibiting flag burning. By focusing our attention on cases further down the slope, an SSA can be used to illuminate problematical aspects of such a prohibition that we may not otherwise appreciate to the same degree.

SSAs invoked against prohibitions on flag burning can thus have value, even if we are skeptical of the literal claims that such arguments make. We may think, for example, that we could prohibit flag burning and still have rational grounds for resisting other prohibitions, or that a prohibition on flag burning is highly unlikely to lead us to prohibit other acts or ideas. But such SSAs can still be used to illustrate how such a prohibition is at least partially a ban on an idea. Thinking about the relevant slippery slope can thus help us appreciate the threat to our values that allowing the case at the top of the slope would represent.

\section{Human Gene Therapy}

Similar points can be made about SSAs invoked in other debates. Consider, for example, those SSAs used to oppose allowing human gene therapy. One could argue that using this technology even for noble reasons-such as eliminating obvious, painful genetic defects-would be likely to lead us to use this technology in more and more cases. At the bottom of the slope could be a variety of scenarios, such as a society in which parents frequently use this technology for the purposes of making

310. See, e.g., id. at 272 (stating that the Johnson decision "was widely offensive to popular patriotic feeling in the U.S."). 
smarter, more conventionally attractive children. Some people in this future society may even try to justify these uses of human gene therapy on the grounds that using gene therapy in these ways "improves" the human race.

The thought of this possible future society is troubling for a number of reasons. For example, we may be struck by the way in which such future people would use human gene therapy to "play God." These uses of gene therapy would arguably be the ultimate technological incursion into that which is natural and represent grave examples of the desacralization or commodification of the luman body. ${ }^{311}$ In addition, we may be disturbed by the motivations of those parents who would use human gene therapy to "improve" their children. We may worry that such parents are too concerned with the "quality" of their prospective offspring and think that such concern is in serious tension with the unconditional love that parents should feel for their children. ${ }^{312}$ The excessive perfectionism of this sort of society is also disturbing. We should fear for the well-being of those future people who would fail to live up to their society's norms. ${ }^{313}$

Arguably, however, these problems would be implicit in even early uses of human gene therapy. Using this technology to cure obvious "defects" would also be an instance of "playing God," and perhaps be representative of the commodification of the human body. Such uses could also encourage parents to focus on the "quality" of their children, as well encourage our perfectionistic tendencies. This, in turn, could lead us to think less of those people who fail to live up to societal norms. Considering possible bottoms of the slope thus provides us with grounds for worrying that even early uses of human therapy will reinforce some of the aspects of ourselves that we view as less than noble. ${ }^{314}$

Using human gene therapy to cure obvious genetic "defects," however, may seem highly justifiable. Doing so could reduce the amount of pain and suffering in the world. But the grounds in favor of using gene therapy can blind us to some of this technology's potential drawbacks. Thinking about possible bottoms of the slope enables us to raise important questions about what using this technology would mean about a society that does so. Such reflections can give us a better understanding of the problems associated with this technology, even if we are unconvinced by

311. For discussion of these worries in relation to various uses of biotechnology, see KIMBRELL, supra note 195.

312. For discussion of how uses of reproductive technologies could reinforce problematical attitudes toward children, see Nancy (Ann) Davis, Reproductive Technologies and Our Attitudes Toward Children, 9 Logos 51 (1988).

313. See generally IAN G. Barbour, Ethics in AN AgE of Technology 196-97 (1993) (discussing how uses of human gene therapy could reinforce prejudice toward the handicapped).

314. For further discussion of how uses of various biotcchnologies could reinforce problematical attitudes, see Davis, supra note 231, at 357-62. 
the literal claims of the relevant SSAs. By considering possible bottoms of the slope, we can take a step back from the uses of human gene therapy that we may be contemplating and consider situations in which their problematical features are magnified. As Davis argues, considering where the uses of various biotechnologies could lead suggests that such uses are "morally premature." 315

\section{The Right to Die}

Similar points can be made about those SSAs used to oppose recognizing a right to die. One could argue, for example, that allowing either active voluntary euthanasia or physician-assisted suicide would eventually be likely to lead to a toleration of the involuntary euthanasia of political or social undesirables, or those whom it is very expensive to keep alive. Independently of what we think about the likelihood of this happening, considering possible bottons of the slope can illuminate possible problems implicit in allowing the cases toward the top.

Perhaps most obviously, a society that tolerates involuntary euthanasia would have extremely corrupt views on the value of human life. Proponents of the relevant SSAs may feel that such problems are implicit in the cases toward the top of the slope. By recognizing a right to die, we would inplicitly grant that human life is not sacred or of infinite value, and that life and death decisions can be made on quality-of-life sorts of grounds. Proponents of the relevant SSAs tend to view this as deeply troubling.

Thinking about possible bottoms of the slope can also illuminate other possible problems with allowing the case at the top. Considering a society that kills people simply because it does not approve of them, or because it is expensive to keep them alive, may lead us to wonder what kinds of pressures the recognition of a right to die would place upon certain patients. Relatives of some terminally ill patients could pressure the patients to choose death; medical personnel may also exert subtle pressures on patients whose lives the medical personnel view as not worth living. In addition, we may have grounds for worrying that special pressures to choose death will be faced by the poor and the handicapped, and perhaps even menibers of certain racial or ethnic minorities. Considering a society with highly corrupt views on human life may thus lead us to wonder whether our society is ready to handle all of the responsibilities that would go along with recognizing a right to die. To gain a full appreciation of the potential problems associated with such a recognition, it is helpful to reflect on possible slippery slopes.

315. Id. at 366 . 


\section{Concluding Remarks}

This Section has argued that considering cases toward the bottom of the slope can illuminate possible problems associated with allowing the case at the top. We may have strong reasons for allowing the case at the top; these reasons can blind us to some of the problems associated with doing so. Sometimes, the problems implicit in cases toward the top will be accentuated or magnified in cases toward the bottom. Considering the latter can thus help us see some of problems with the former in a clearer light. Such reflections can lead us to ask important questions about what allowing the case at the top would mean about the society that does so. These questions may give us grounds for resisting the case at the top, even if we think that the claims of the relevant SSAs do not.

It should be emphasized, however, that such considerations will not always be conclusive. Refusing to allow a practice may also head us in a problematic direction and raise troubling questions about what this refusal means about our society. By not recogmizing a right to die, for example, we arguably fail to respect people's autonomy and tolerate an increased amount of pain and suffering in the world. ${ }^{316} \mathrm{~A}$ good case can be made for thinking that these consequences are more troubling than the possible consequences of granting that human life is not sacred, or tolerating a situation in which people's life and death decisions would be influenced by other people's views and values. ${ }^{317}$

As Jeffrey Whitman argues, there really may be "no escaping the tragic choice." ${ }^{318}$ Allowing the practice under consideration may be problematical; refusing to do so may be deeply troubling as well. This Section has argued, however, that in order to best see the problems involved in accepting the case at the top of the slope, it will frequently be helpful to reflect on cases toward the bottom. While such reflections will not necessarily be conclusive, they can help to give us a better appreciation of what accepting the case at the top would mean about the society that does so.

\section{Deeper Concerns}

The view of SSAs sketched in this Part may also enable us to address some of the deeper concerns that lie behind people's uses of SSAs. In addition, this view may help to explain why people often invoke such arguments in a less than rigorous manner. A.s discussed above, SSAs are often made in response to perceived threats to a people's ideologies. ${ }^{319}$ Proponents of SSAs tend to hold that allowing $A$ would represent the

316. See supra notes 262-63.

317. See, e.g., Arras, supra note 8, at 298-99.

318. Whitman, supra note 31 , at 93 .

319. See supra Part V.A.2. 
corruption of some important value. They therefore worry about the further corruption of that value that our allowing $A$ may invite.

As Whitman notes, it can be difficult to give a voice to all of our values; rational, philosophical discourse may not always be adequate for the task. $^{320}$ Proponents of SSAs generally believe that there is some connection between $A$ and $B$ : Both represent a corruption of the same value, although this corruption is more accentuated or apparent in the case of $B$. In an attempt to express their views on the problems associated with allowing $A$, it is rather natural for proponents of SSAs to use the slippery slope terminology because this terminology enables them to emphasize the connections between $A$ and $B$. Whitman even suggests that appeals to SSAs are sometimes expressions of "psychological angst" toward the thought of allowing $A .^{321}$ In order to express their moral sentiments, people may resort to the slippery slope terminology because doing so is more intellectually respectable than simply professing an emotive dislike of $A$ and leaving their remarks at that. ${ }^{322}$

Insofar as SSAs are expressions of moral sentiments that the claims of rational arguments are unable to fully capture, simply focusing on the claims of SSAs will prevent us from adequately addressing the deeper concerns that underlie the uses of such arguments. Showing that we can draw a rationally defensible line on the slope, and that allow $A$ would be highly unlikely to lead us to allow other cases, may not alleviate the proponent of an SSAs' concerns. She often will be concerned about what allowing $A$ represents and about what allowing it would mean about our society, independently of whether allowing it would lead to a slide down a slippery slope. And even if we can show that we could allow $A$ and have rational grounds for resisting $B$, this does not necessarily mean that there are no important connections between the two. SSAs may often act as a subterfuge for deeper concerns.

As Whitman argues, expressions of moral emotions deserve a role in our discourse, even if such emotions are not always expressed in the most intellectually respectable manner. ${ }^{323}$ Often, allowing $A$ would threaten values that are important to a significant segment of our population. This threat deserves our consideration, even if proponents of the relevant arguments do not articulate their concerns in the most rigorous fashion. This Part has argued that reflecting on possible bottoms of the slope will often best enable us to appreciate this threat. This, in turn, will help us address some of the deeper concerns that lie behind people's invocations of SSAs.

320. See Whitman, supra note 31 , at 93-94.

321. Id. at 94 .

322. Cf. id. (suggesting that appeals to SSAs are often attempts "to objectify ... 'psychological concern[s]' in a philosophically legitimate manner').

323. See id. at 95 . 
However, van der Burg argues that discussion about SSAs is "often futile" because proponents and critics of such arguments tend to have such fundamentally different outlooks. ${ }^{324} \mathrm{He}$ says that discussion about SSAs often

is not really a rational discussion of facts and norms (though it sometimes pretends to be) because acceptance of the arguments so strongly depends on one's basic outlook. This is one more reason to be careful with the argument in moral debate-it usually will not help us any further but, rather, will frustrate the discussion. Therefore, it seems more fruitful to analyze and discuss the more fundamental questions that are hidden behind the use of the argument. This probably will be more effective in preventing the developments that are feared than the rhetorical and emotional use of the $[\mathrm{SSA}]^{325}$

While it is true that proponents and critics of particular policies often talk past each other and ignore differences in their values, this does not have to be the case. Often, both proponents and critics of a practice will share some of the same values; it would be helpful to attempt to steer the discussiou toward these shared commitments. Proponents and critics of SSAs can attempt to engage in a dialogue about cases toward the bottom of the slope, and articulate why these cases are troublesome. They can then use this dialogue to shed light on the possible problems involved with allowing $A$. Considering cases toward the bottom of the slope can help further the discussion because it can provide a better understanding of the corruption that allowing $A$ would represent to proponents of the relevant SSAs. Such reflections can also lead us to ask deeper questions about what allowing $A$ would mean about our society and illuminate the threat that such an allowance may pose to values that are significant to large segments of the population. This, in turn, may offer us a way to further, rather than to frustrate, the discussion. As this Part has argued, sometimes such reflections will give us grounds for resisting $A$, even if we think that the claims of the relevant SSAs do not.

\section{CONCLUSION}

SSAs can play a number of important roles in legal reasoning. The literal claims of some SSAs may give a court grounds for resisting the practice or policy under consideration. And even if a court thinks that such claims do not do this, considering SSAs can at least motivate that court to take steps to reduce the risk of sliding down the relevant slopes.

This Comment has also argued that reflecting on cases toward the bottom of the slope can shed light on problems associated with the case at

324. van der Burg, supra note 29, at 65 .

325. Id. 
the top. Such reflections can highlight the ways in which the practice under consideration is in tension with important values and help us address some of the deeper concerns that underlie people's invocations of SSAs. This, in turn, may enable us to further the discussion in debates in which SSAs are invoked.

There are thus good grounds for rethinking some of the roles that SSAs can play im legal reasoning. People who evaluate SSAs tend to focus their attention only on the literal claims of such arguments. If we think that we can draw a rationally defensible line along the slope, and that we can allow $A$ and prevent the relevant slippage, we tend to think that the SSAs under consideration fail to provide us with reasons for resisting $A$. This Comment has argued that such an assessinent is precipitate. Sometimes, reflecting on the bottoin of the slope can provide us with grounds for resisting $A$, even if we think that the claims of the relevant SSAs do not. In cases in which major values are at stake, it would be irresponsible to fail to engage in such reflections. 
